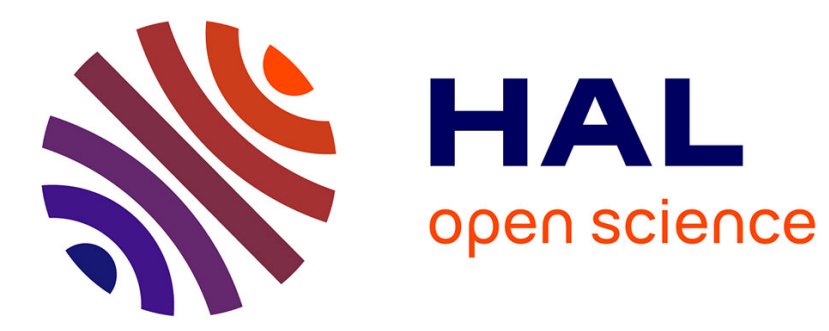

\title{
The college-to-work transition during the 1990s: evidence from Sweden.
}

\author{
Marie Gartell
}

\section{To cite this version:}

Marie Gartell. The college-to-work transition during the 1990s: evidence from Sweden.. Applied Economics, 2011, pp.1. 10.1080/00036846.2010.543078 . hal-00676228

\section{HAL Id: hal-00676228 \\ https://hal.science/hal-00676228}

Submitted on 4 Mar 2012

HAL is a multi-disciplinary open access archive for the deposit and dissemination of scientific research documents, whether they are published or not. The documents may come from teaching and research institutions in France or abroad, or from public or private research centers.
L'archive ouverte pluridisciplinaire HAL, est destinée au dépôt et à la diffusion de documents scientifiques de niveau recherche, publiés ou non, émanant des établissements d'enseignement et de recherche français ou étrangers, des laboratoires publics ou privés. 


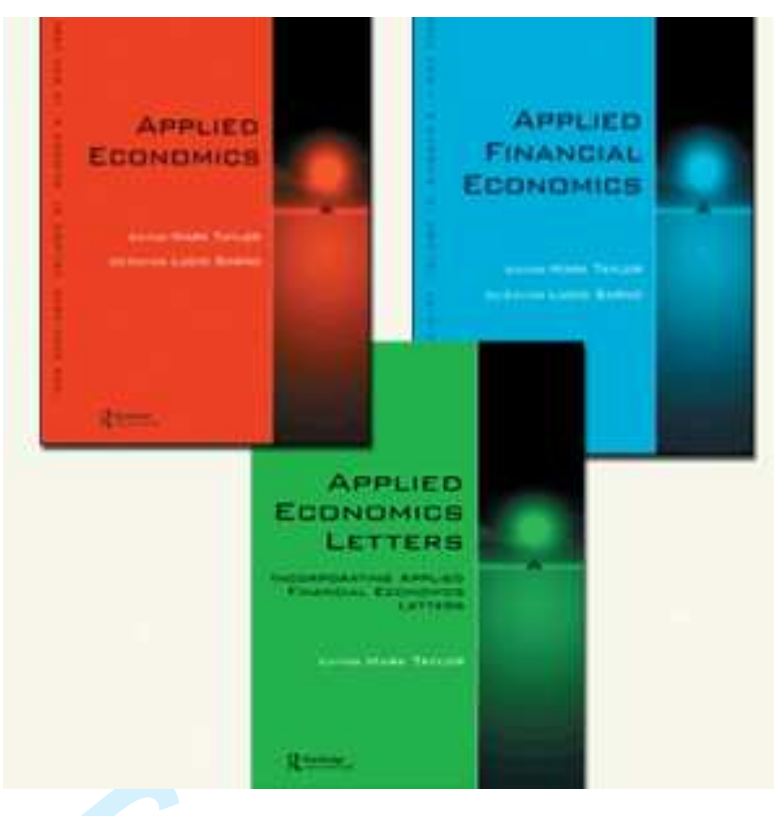

The college-to-work transition during the 1990s: evidence from Sweden.

\begin{tabular}{|c|c|}
\hline Journal: & Applied Economics \\
\hline Manuscript ID: & APE-08-0812.R1 \\
\hline Journal Selection: & Applied Economics \\
\hline $\begin{array}{r}\text { Date Submitted by the } \\
\text { Author: }\end{array}$ & 21-Nov-2010 \\
\hline Complete List of Authors: & Gartell, Marie; Institute for Futures studies \\
\hline JEL Code: & $\begin{array}{l}\text { A22 - Undergraduate < A2 - Economics Education and Teaching of } \\
\text { Economics < A - General Economics and Teaching, C41 - Duration } \\
\text { Analysis < C4 - Econometric and Statistical Methods: Special Topics } \\
<\text { C - Mathematical and Quantitative Methods, I21 - Analysis of } \\
\text { Education < I2 - Education < I - Health, Education, and Welfare, } \\
\mathrm{J} 22 \text { - Time Allocation and Labor Supply < J2 - Time Allocation, } \\
\text { Work Behavior, and Employment Determination/Creation < J - } \\
\text { Labor and Demographic Economics, J64 - Unemployment: Models, } \\
\text { Duration, Incidence, and Job Search < J6 - Mobility, } \\
\text { Unemployment, and Vacancies < J - Labor and Demographic } \\
\text { Economics }\end{array}$ \\
\hline Keywords: & College-to-work, Unemployment, Duration analysis \\
\hline
\end{tabular}




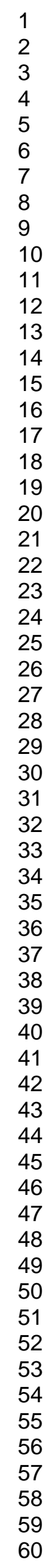

\section{SCHOLARONE ${ }^{m}$ \\ Manuscripts}

7

25

26

27

29

30

32

33

34

36

37

38

41

42

44

45

46

47

48

49

51

52

53

54

55

57

58

59

60 


\section{The college-to-work transition during the 1990s: evidence from Sweden \\ M. Gartell \\ Institute for Futures studies, Box 591, 10131 Stockholm, Sweden \\ From 19 October 2009: The public Employment Service, Department of Analysis, 113 \\ 99 Stockholm, Sweden \\ E-mail: marie.gartell@arbetsformedlingen.se}

This paper analyses the time it takes for Swedish college graduates to start a full time job that lasts for six months or more. The focus is on the transition over time during the period 1991 to 1999. This period covers both upturns and downturns of the business cycle, providing a unique opportunity to consider the importance of the timing of graduation. The results show that the risk of unemployment and the unemployment duration have varied considerably with the business cycle, both within and between cohorts. For example, field of education is of more importance for the outcomes during recessions. Further, the relative risk of unemployment has decreased over time for individuals with the highest degree of education whereas the unemployment duration has increased, indicating that the selection into unemployment for this group may have changed over time. This is interesting, not least in the light of the sharp expansion of the higher educational system during the studied period. 


\section{Introduction}

It is of great importance to study the transition from college to work. The time it takes to gain steady employment following graduation has effects on the returns to education, and accordingly it may have long-term effects on skill accumulation and incomes. ${ }^{1}$ Consequently, it will affect the tax income for the government. Hence, the issue addressed in this paper is important both from an individual perspective and from an economic growth perspective. Moreover, to study the transition from college to work has become increasingly relevant during the last decades given the great expansion of the higher educational system, not least in Sweden.

There are very few previous studies on unemployment duration at graduation. Betts et al. (2000) estimate the time it takes for Canadian college graduates to start a full time job that lasts for six months or more. The speed of transition both within and between cohorts is investigated. A related literature examines the long-term effect on earnings of graduating in a recession. $^{2}$

Previous studies on Swedish data are mainly focusing on re-employment due to different unemployment benefit systems. ${ }^{3}$ No previous study on Swedish data emphasizes only highly educated, hence, nor do they explore the transition to work for

${ }^{1}$ Gartell (2009) shows that Swedish college graduates who get unemployed at graduation have considerably lower future earnings as compared to college graduates who do not experience any unemployment at graduation. Holmlund et al. (2006) show that working experience subsequent to graduation is important for individual incomes at 35 years of age. Nordström Skans (2004), studying high school graduates, shows that unemployment during the first year after high school graduation has serious long term effects on future incomes.

${ }^{2}$ See e.g. Stevens (2007), Oreopoulos (2008).

${ }^{3}$ See e.g. Harkman (1987), Albrecht et al. (1989), Edin (1989), Edin and Holmlund (1991), Höjgård (1994), Korpi (1995), Carling et al. (1996), Thoursie (1998) and Jans (2002). 
this group. This paper adds to existing literature by specifically examining the transition to work for college graduates.

During the 1990s the business cycle fluctuations were significant, which is likely to have affected the transition to work during the period. ${ }^{4}$ Business cycle variations are likely to be related to individual opportunities to get a job at graduation as well as to the individual risk of exiting unemployment (if unemployed at graduation), e.g. there are fewer job offers in recessions. Moreover, human capital may depreciate with the unemployment duration, further reducing the possibility of employment. ${ }^{5}$ In contrast, unemployment during economic upturns may send a relatively more negative signal to employers, or individuals getting unemployed during good times are a more negatively selected sample. These factors may increase the unemployment duration in good times as compared to bad.

Graduates from Stockholm and Uppsala University during 1991 to 1999 are studied. Data, provided by the Institute for Labour Market Policy Evaluation (IFAU), consists of a number of administrative data sets covering the whole population of 16-64 years old.

The risk of unemployment is estimated using a probit model, whereas the duration to first job is analyzed using a proportional piece-wise linear hazard model. Two main points are investigated. First, do patterns of transition to work differ between graduates

${ }^{4}$ Thoursie (1998) studies individuals with different educational levels and shows that the effect of education on the unemployment duration varies with the business cycle. Her study covers the population 24-54 years old in Sweden.

${ }^{5}$ See e.g. Edin and Gustavsson (2008). 
at different points in the business cycle? Second, given the same graduation year, does the transition to work differ between graduates?

Examining the college-to-work transition, outcomes across the business cycle may be correlated with individual characteristics, observed or/and unobserved. One might expect the distribution of individual observed and unobserved characteristics to be similar across cohorts of graduates, i.e. across the business cycle. However, the timing of graduation might be endogenous. Although the main purpose of this paper is to describe the college-to-work transition rather than to establish a causal relationship, parental background and grade point average from high school are used to control for unobserved ability. This is a common approach in the educational literature. Furthermore, a term for unobserved heterogeneity is included, and the risk of unemployment and the unemployment duration is estimated simultaneously.

The paper proceeds as follows. The next section provides some background. In section 3 the theoretical framework is presented and in section 4 data used is described. Empirical considerations are discussed in section 5. Section 6 presents the results of the analysis. Section 7 concludes.

\section{Background}

During the 1990s Sweden experienced the deepest recession since the Great Depression in the 1930s. Hence, the studied period covers extreme variations in the business cycle and a unique opportunity to study the importance of the business cycle for the transition 
to work. Fig. 1 shows the unemployment rates during the period. The fluctuations have been significant during the period, but not as pronounced for highly educated as compared to other groups. Fig. 2 displays the net employment rates, i.e. the difference between jobs created and jobs destroyed, and shows that there is also variation within the group of highly educated. For example, to have a higher level of degree was more favourable in terms of net employment rates during the second half of the 1990s, whereas it was more favourable to have a shorter university education during the first half.

$<$ Fig. 1 about here $>$

< Fig. 2 about here $>$

Furthermore, during the 1990s the share of college students in Sweden increased dramatically, at the same time as the number of graduates was large. The number of new students increased with $50 \%$ during the 1990s, and the number of individuals with a university degree increased with $25 \%$. Moreover, the share of the population with a long university education increased relatively more as compared to individuals with a shorter university education. ${ }^{6}$ The share of a yearly cohort with a university degree has been fairly constant for cohorts born before 1965, but has increased considerably for cohorts born after $1965^{7}$

In addition, the size of the cohorts has varied (see Fig. 3). The cohort one belongs to will matter for the number of graduates, the educational level of the population and the

\footnotetext{
${ }^{6}$ The Swedish Labour Force Survey, See Gartell (2010) for details.
} 
size of the cohort exiting the labour force. This could possibly affect both the risk of unemployment and the unemployment duration. ${ }^{8}$

$<$ Fig. 3 about here $>$

\section{Theoretical framework}

Search theory considers unemployed workers who maximize their utility. They do so by choosing a set of acceptable wage offers at each point in time. This set is defined by the reservation wage; the unemployed individuals will accept all offers above or equal to their reservation wage and reject offers less than their reservation wage. ${ }^{9}$ The reservation wage chosen by the individual will affect the probability of accepting a job offer, given that he/she has not previously done so.

The probability of acceptance is dependent on the individual reservation wage, the probability of receiving a job offer and individual search activity. The higher the reservation wage the lower the risk that an individual accepts a job offer and, consequently, leaves unemployment. The reservation wage may be dependent on time spent in unemployment, i.e. the duration. Theoretically, it will decrease with the duration. Empirically, this means that the probability of leaving unemployment will increase. On the other hand, the estimated probability of accepting a job offer is an average of the probabilities of the surviving individuals at that time, this may be a

\footnotetext{
${ }^{7}$ National Agency for Higher Education (2001).

${ }^{8}$ See e.g. Nordström Skans (2005) who shows that a large youth cohort has a positive effect on the local labour market in terms of unemployment rates for young workers.

${ }^{9}$ See Lancaster (1979) for a more detailed model, and Jans (2002) for a simplification of the same model.
} 
selected sample, and the probability could, as a result, fall with the duration.

The reservation wage is, however, hard to observe. The most natural way to empirically specify a search model is by using duration data and estimate the variation in the probability of leaving unemployment (as a function of time).

According to search theory, higher educated individuals have higher reservation wage. ${ }^{10}$ This means that more highly educated individuals may have trouble finding acceptable jobs. In contrast, it is assumed that highly educated individuals will have more job opportunities. Theoretically, an individual can accept a job offer below his/her educational level, but will not receive job offers above his/her educational level. The effect of education is not clear-cut; there is a positive effect due to number of job offers but a negative due to a higher reservation wage.

For new graduates other factors such as e.g. to find a job that corresponds to one's education could be of great significance. Moreover, studying the transition to work across time, the reservation wage may vary as a result of that e.g. $i$ ) the supply of highly educated vary, ii) the demand for highly educated vary, and iii) the business cycle fluctuations - there is e.g. a higher risk associated with turning down a job offer in a recession due to fewer job offers. These factors could both negatively and positively relate the educational level to the risk of unemployment and the unemployment duration. Van der Klaauw et al. (2005) show that as graduation approaches, students increase their job search effort and lower their reservation wage. Furthermore, they 
show that the unemployment rate at graduation is important; mean wage offers are significantly lower in periods when the unemployment rate is high. They also find substantial returns to work experience, which suggests that individuals are relatively less selective in choosing their first job i.e. reservation wages will be lower.

\section{Data}

Data are provided by IFAU and consist of a number of administrative data sets from Statistics Sweden and the Public Employment office, covering the whole population of 16-64 years old in Sweden. In this paper all graduates from Stockholm and Uppsala University during 1991 to 1999 are used. Unemployment immediately (within a year) upon graduation is considered. The unemployment spell is studied up to the point where individuals find a full-time job, lasting for six months or more. Durations are (right) censored after two years. Hence, individuals are followed for at most three years subsequent graduation.

The individual-level records in the events database (Händel) are used to study the unemployment duration. Registration at a public employment office is compulsory for anyone receiving unemployment benefits. For a student to be entitled to benefits he/she must have been registered as unemployed for 90 days. ${ }^{11}$ This should provide an incentive to register as soon as one realizes the risk of unemployment. A benefit period consists of 300 benefit days corresponding to 15 months (if on full time). This period can be prolonged at most one time with a maximum of 300 benefit days.

\footnotetext{
${ }^{10}$ Kettunen $(1994,1997)$.
} 
Studying the risk of unemployment, all registrations at the public employment office are considered. Whereas examining the unemployment duration only individuals registered as full-time unemployed and able to accept employment immediately will be included. Data further contains information regarding destination after exiting unemployment. The reason for exiting unemployment is in the great majority of cases that individuals received employment; regular, temporary or reemployment at previous employer. A rather big group is the "contact broken" category (about 20\%); these individuals will be considered as having found employment. Further, some individuals return to regular education, i.e., education outside the labour market programs. More than $80 \%$ of the individuals are included in the employment categories or the contact broken category. About $10 \%$ are found in the education category, and less than $10 \%$ leave for other reasons. The reason for leaving unemployment does not vary considerably across graduation years. $^{12}$

The duration of unemployment, starting within a year following graduation, will be considered. The unemployment spell may well start before graduation; $94 \%$ of the unemployment spells however start the same semester as registered graduation, or later. All unemployment spells ending before graduation are excluded. If the gap between two subsequent unemployment periods is less than 6 month, I will consider it as ONE period. ${ }^{13}$ The reason is to avoid considering very temporary jobs as employment. About

\footnotetext{
${ }^{11}$ The Swedish Unemployment Insurance Board (IAF), Fakta-PM 3:2005.

${ }^{12}$ However, there are some changes in the coding of data over time. There are some previous studies using models for competing risks at reemployment; these studies show that different transitions are governed by different mechanisms. See e.g. Edin (1989) and Thoursie (1998).

${ }^{13}$ See e.g. Betts et al., where 6 months is used to define a stable employment.
} 
$14 \%$ have a gap between two subsequent periods that are greater than zero, and about $5 \%$ have a gap that is greater than 20 days.

Individuals will be censored if their unemployment spell exceeds 2 years (about $1 \%$ ). Also, they will be censored due to "other" reasons if disappearing out of the data for any other (unknown) reason. Individuals not found in any other register the year of graduation will be dropped. Hence, information about age, gender and so forth is missing (less than $2 \%$ of the population); these are likely to be exchange students or non-Swedish citizens.

The spring and fall semesters range from January 20 to August 30 and September 1 to January 19 respectively. The semester of graduation is known, but not the exact date. No time varying covariates are used because the unemployment spells, on average, are too short to explore yearly variations. The duration in the $50^{\text {th }}$ percentile is less than 6 months (see Appendix Table A1 and Fig. A1). ${ }^{14}$

If an individual has several registered graduation years, the latest is used. If there are several degrees, at different levels, the same year, then the highest-level degree is used. Further, if an individual have several degrees within the same field of education, an indicator is created to specify that there were actually several degrees within the same field and only one degree is kept. Finally, if there are several degrees within different fields, one is randomly chosen and a variable is created to indicate whether the

\footnotetext{
${ }^{14}$ This may be compared to the median duration for Canadian college students which is 15 month, see Betts et al. (2000).
} 
individual have several degrees (about $0,003 \%$ of the population).

Fixed variables used, i.e. variables observed in the beginning or before the unemployment spell, are age (and age squared), sex, country of birth, educational background such as length and field of education, year and semester of graduation, children $^{15}$, parental education. Moreover, an indicator for the type of unemployment benefit the individual is entitled to, year of first registration in higher education and grade point average from high school are included in some specifications (see Appendix Table A2 for details).

The total number of graduates in the period 1991 to 1999, from Uppsala and Stockholm University, were 39 376. After the data processing there are 38013 individuals, out of which 14644 experienced unemployment at graduation. Out of these 14 644, 7288 are registered as unemployed and able to accept employment immediately. Only these 7288 individuals are used in the duration analysis. ${ }^{16}$ For more detailed descriptive statistics see Appendix Table A3.

$<$ Table 1 about here $>$

\footnotetext{
${ }^{15}$ There is information about number of children in different age groups in the household but no information about whom the children belong to. Consequently, for students living at home, it is possible that they will be registered as having e.g. children older than 18 , but those children are in fact themselves (or possibly siblings). Therefore, children above the age 18 will be excluded from the analysis. A variable for "had a child during the first year after graduation" will be included as a sensitivity analysis.

${ }^{16}$ The other unemployed individuals are not considered to be able to accept a job offer immediately for a number of different reasons. In previous studies on unemployment duration only individuals able to accept a job immediately are considered; only these individuals may end their unemployment immediately upon receiving a job offer.
} 
Table 1 shows that the number of graduates has increased during the 1990s and that the share of students experiencing unemployment at graduation has varied with the business cycle. Further, the share getting unemployed at the end of the period are smaller as compared to the beginning. This pattern corresponds to some evidence presented in Gartell et al. (2010). Gartell et al. find quite strong evidence that the increased share of highly educated individuals, at least partly, has been driven by increased demand for this group. Granqvist and Regnér (2007) present results showing that the income premium of higher education have increased during the same period.

\section{Empirical considerations}

The risk of unemployment at graduation is estimated using a probit model. To study the unemployment duration, a proportional piecewise linear hazard model will be estimated using aML software. ${ }^{17}$ This model allows the hazard to be different over each time interval. Moreover, it is possible to introduce a term for unobserved heterogeneity, i.e. the duration dependence can be estimated conditioning on observed covariates and unobserved heterogeneity. Assumptions made are that the heterogeneity is independent of the observed covariates, starting times and censoring times. Further, it is assumed that the heterogeneity has a known distribution and enters the hazard function multiplicatively. These assumptions can not be tested; if the assumptions are not fulfilled the unobserved heterogeneity term can introduce errors into the model. However, one may argue for the likelihood of those conditions being fulfilled or not. The unobserved heterogeneity term can though be used to test the stability of the results. 
If the results are stable for the inclusion, there is less reason to worry about omitted variable bias.

To examine the importance of the timing of graduation, dummy variables for each graduation year are included and the model is estimated separately for different graduation years. As already mentioned, there may be other factors linked to the year of graduation that may influence the result. First, there has been a great expansion of the higher educational system. Second, there have been fluctuations in cohort sizes and in the net employment rates for highly educated during the studied period. To try and identify or disentangle these different effects are not within this study. ${ }^{18}$

Only registered unemployment spells are considered. Considering only registered unemployment will on one hand avoid including individuals that e.g. did not have an employment but continue to study, or work abroad. On the other hand, individuals might be unemployed without being registered at the public employment office. However, the incentives to register are rather high. ${ }^{19}$

In this paper only graduates are used. Out of all individuals with a university education corresponding to three years or more, about $80 \%$ graduate..$^{20}$ In general, students may be divided into two groups; program students and course students. Program students enter

\footnotetext{
${ }^{17}$ See Bossfeld and Rohwer (2002) and Lillard and Panis (2003) for description of the model.

${ }^{18}$ See e.g. Andersson (2000) for a discussion of how to identify age, period and cohort effects respectively.

${ }^{19}$ More than $90 \%$ of individuals reporting unemployment where registered as unemployed at a public employment office. Moreover, the share of individuals reporting unemployment who have been in contact with a public unemployment office has been rather stable during 1992-1997. See Statistics Sweden (1993) and the Swedish National Labour Market Board (1998).
} 
a program usually lasting for 3 years or more, whereas course students register at separate courses typically lasting for at most one semester. Separate courses may be combined to correspond to a program. However, 7 years from their first registration only $10 \%$ of the course students have a degree and another $10 \%$ have achieved three years full time study without graduating. Eleven years from their first registration, about $70 \%$ of the program students have graduated. The main reason for using only graduates is that the time of graduation is registered. However, the registered date of graduation may not necessarily correspond to the actual date of graduation. Completing their studies, individuals do not routinely graduate but are required to hand in an application to be registered as graduates.

Only graduates from Stockholm and Uppsala University are studied, the reason is to reduce potential problems of differences between universities and local labour markets. Moreover, the focus is on the importance of the timing of graduation not on regional differences. Students from Stockholm and Uppsala University basically graduated into the same labour market. For graduates in 1991, about $80 \%$ of the graduates from Stockholm University worked within the county of Stockholm or Uppsala one, five and ten years following graduation. For graduates from Uppsala University about 55\% worked within the region. Individuals working outside the region are quite evenly distributed among other counties. ${ }^{21}$ The Stockholm region labour market differs in some aspects compared to other regions. Stockholm is the capital of Sweden and by far the largest city, and unemployment rates are generally lower as compared to other parts of

${ }^{20}$ National Agency for Higher Education (2005).

${ }^{21}$ See e.g. Gartell and Regnér (2002, 2005). 
the country.

The selection of individuals into university studies may vary with the business cycle at the time for admission. Furthermore, the increasing supply of graduates over time may suggest less selection into university studies. A single administrative authority on the national level handles the admission; number of applicants often outnumbers available slots. $^{22}$ Grade point average from high school is generally used in the admission procedure.

The selection out of university studies may also vary with the business cycle. Individuals may e.g. postpone graduation in recessions, potentially making graduates in recessions a relatively selected sample. Consequently, cohorts of graduates can differ in their ability, affecting the probability of unemployment and the risk of exiting unemployment. The option to postpone graduation is however somewhat limited by the possibility of financing. Moreover, the graduation frequency may fluctuate with the business cycle; during good times it might be more likely to receive a job offer without an actual degree. Variables commonly used to control for ability are grades from high school and parental education. Further, the quality of education is possibly affected by the expansion of the higher educational system.

In Appendix, Table A3, descriptive statistics for the different graduation years are presented. The year of first registration at a university will be included as a control

${ }^{22}$ See National Agency for Higher Education $(2004,2006,2007)$ for details on higher education in Sweden. 
variable. This should, in combination with information about graduation year, be a good estimate of circumstances at admission as well as the time spent in education. Moreover, the level of education and grade point average from high school are included in the analysis.

\section{Results}

Both the risk of unemployment and the unemployment duration across the 1990s are estimated. The risk of unemployment at graduation is estimated using a probit model. ${ }^{23}$ The unemployment duration is estimated using a piece-wise linear proportional hazard model. Estimating the unemployment duration, only individuals registered as unemployed and able to accept a job offer immediately are included.

\section{Transition to work between cohorts}

In this section, only year dummies are included to estimate the effect of graduation year on the probability of unemployment and the relative risk of leaving unemployment. Fig. 4 shows that the probability of unemployment varies considerably across graduation years; the probability of unemployment for graduates in 1993 is $2.5 \%$ higher than for graduates in 1995, the probability for graduates in 1999 is $15.5 \%$ lower as compared to the reference year (results are also presented in Table A4 in Appendix). It is interesting to note that the probability of unemployment is lower for individuals graduating towards the end of the 1990's, considering the increasing supply of highly educated during the decade. 
Fig. 5 shows the relative risk of exiting unemployment, if unemployed at graduation, across graduation years (results are also presented in Table A4 in Appendix). The result corresponds to the result for the probit model; the same years that increase the risk of unemployment will shift the baseline down, i.e. reduce the risk of exiting unemployment. And years with a relative low risk of unemployment will shift it up.

$<$ Fig. 4 about here $>$

$<$ Fig. 5 about here $>$

Further, Fig. 6 shows that there is a nonlinear relationship between time and the risk of exiting unemployment. The time intervals used are 0-3 months, 3-6 months, 6-12 months, 12-18 months and finally 18-24 months. There is a peak at 3 months, most likely due to the fact that an individual has to be registered as unemployed for three months before receiving any unemployment benefits. Once benefits are received, the risk of exiting unemployment decreases up to 6 months and then change direction and increases until 18 months and thereafter flattens. At 18 months the benefit period expires, if no extension is accepted. ${ }^{24}$

$<$ Fig. 6 about here $>$

\footnotetext{
${ }^{23}$ Weights were applied, but did not influence the results. Hence; nonweighted estimates are presented.

${ }^{24}$ The shape of the base line is very similar across individuals graduating during the spring and fall semesters respectively. The results are not presented but may be obtained from the author upon request.
} 
The effect of observable covariates. Different covariates are included to investigate whether any of the variation across graduation years may be explained by observable factors. For neither the risk of unemployment nor the unemployment duration, are the coefficients of graduation year much affected by the inclusion of various covariates, suggesting little selection on observables across time (see Appendix Table A4). Note that this result also holds including grade point average from high school and parental educational level; traditionally considered to be highly correlated with individual ability.

Further, the inclusion of control variables reveals that the risk of unemployment is lower if graduating during the spring as compared to the fall, the probability of unemployment increases with age and is reduced if having children between the ages 03 years and 11-15 years (see Appendix Table A4). ${ }^{25}$ Examining the educational characteristics included show that to have a degree within sciences, technology or healthcare reduces the probability of unemployment compared to having a degree within social science, whereas a degree within the fields arts/humanities and service/tourism increases the probability. More unexpectedly, the higher the level of education the higher the relative probability of unemployment at graduation.

Moreover, the year the individual first registered at a university was included. The year of first registration had some significant effect but did not affect the coefficients of the graduation years much (78 individuals lack this information), indicating that the

\footnotetext{
${ }^{25}$ Also, to have a child during the first year after graduation has a significant and negative effect. However, it does not affect the other estimates. I chose to leave this variable out of the basic specification since the exact timing of childbirth is unknown.
} 
circumstances at admission are of little importance for the estimated effects. ${ }^{26}$

Turning to the risk of exiting unemployment, if unemployed at graduation, the inclusion of different control variables reveal that to graduate during spring reduces the risk of exiting unemployment, the risk of exiting unemployment is reduced with age, to be born in Sweden increases the risk and to have children between 7-10 years reduce it. ${ }^{27}$ To include information about the parental background did not have any significant effects. $^{28}$ These results are analogous to the results for the probability of unemployment at graduation; with the exception that the probit model showed that to graduate during spring reduced the risk of getting unemployed. Hence, to graduate during spring means a lower risk of unemployment but once unemployed the unemployment spell is longer. This might be explained by the fact that it is easier to find, at least a temporary job, during the summer. ${ }^{29}$ A temporary job may work as a stepping stone for a more stable employment avoiding unemployment during the first year subsequent graduation. However, once unemployed, the probability of exiting unemployment i.e. to receive a job offer may be relatively low due to e.g. vacations.

Further, examining the educational characteristics reveals that to have a degree within teaching, technology or health care increases the risk of exiting unemployment relatively to social science. This corresponds to the results from the probit model, i.e.

\footnotetext{
${ }^{26}$ The results are not presented but may be obtained from the author upon request. The year of first registration was included both as a continuous variable and as dummy variables.

${ }^{27}$ A variable for "had a child during the first year" was included; the results were robust for this inclusion.

${ }^{28}$ Grades from high school were included for a sub sample of 4254 individuals. The estimated risk of exiting unemployment is 1.10 , i.e., higher grades mean a higher risk of exiting unemployment. The other estimates are stable for the inclusion, however, the baseline between 18 and 24 months changes to positive but are not significant.
} 
the same fields of education that are associated with a relative high risk of unemployment at graduation are also associated with relatively long unemployment spells. A higher level of education increases the risk of exiting unemployment i.e. of receiving a job. This is in contrast to the results in the probit model, where the estimated risk of getting unemployed was greater the higher the level of education. One explanation may be that more highly educated individuals are possibly more selective in what jobs to accept, i.e. their reservation wage is higher. An alternative explanation may be that less employable individuals stay longer in education because they have a hard time to obtain employment. And once unemployed, their reservation wage decreases and the risk of accepting a job offer increases. For individuals with a lower educational level the relationship is reversed. The risk of unemployment is lower but once unemployed it is a more long-lasting problem. ${ }^{30}$

\section{Transition to work within cohorts}

In this section, the model is estimated separately for graduates in different years (see Appendix Table A5 and A6). ${ }^{31}$ The reason is to examine the importance of different covariates at different times of the business cycle.

First, the results for the probit model are discussed (see Appendix Table A5). The estimated effects of the covariates do differ between years of graduation though in most

\footnotetext{
${ }^{29}$ A majority of students that graduate during spring and who experience unemployment have an unemployment period that begins before or during the summer.

${ }^{30}$ Also type of unemployment benefit was included; the results are stable for this inclusion. The results may be obtained from the author upon request.

${ }^{31}$ Some estimations have been done on a sub-sample including only Swedish born individuals, and the results are robust. The results can be obtained from the author upon request.
} 
cases the estimates have the same direction over time. One exception is the estimates for humanities that vary between a significant estimate of $-10 \%$ and a significant and positive estimate of $13 \%$. There is some evidence that the estimated effects of field of education in general are larger during periods of relatively high aggregate unemployment rates. The importance of the level of education also differs across years. The effect of having a higher degree has a relative negative trend over time, i.e. the relative risk of unemployment decreases. ${ }^{32}$

Estimating the hazard model, the graduation years will be grouped as follows; 19911993, 1992-1994, 1993-1995, 1994-1996, 1995-1997, 1996-1998 and 1997-1999 to obtain more observations (see Appendix Table A6). There is some variation in the estimated effects of the covariates across graduation years, though for the most part the estimates have the same sign. The effects of field of education vary considerably across years. The effect of humanities changes sign between years, i.e. it varies between 1.19 and 0.86. Again there is some indication that field of education is more important during times considered as bad. Hence, estimated effects are relatively large during recessions. The only apparent trend found is the decreasing trend of exiting unemployment for individuals with the highest level of education. Remember, during the studied period there has been a sharp increase of the number of highly educated, and even more so the higher the level of education. However, as suggested in the probit model, the risk of unemployment did decrease across time. The decreasing risk of exiting unemployment may possibly, therefore, be explained by that the selection into

\footnotetext{
${ }^{32}$ Moreover, average grades from high school were included for a sub sample of 21959 individuals. The estimate is significant and negative (-0.09), i.e. higher grades means lower risk of unemployment. However, to include grades did not have much effect on the other estimates.
} 
unemployment for this group may have changed across time. The level of the baseline for the different samples is not really comparable; though the shape is similar.

\section{Sensitivity analyses}

To test for exit selection and the robustness of the results a term for unobserved heterogeneity is included in the model. Further, potential entry selection is considered estimating the probit and hazard model simultaneously.

Exit and Entry selection. To test for exit selection, i.e. if individuals who receive a job are a selected sample compared to individuals still unemployed at time $t$, a term for unobserved heterogeneity is included in the hazard model. Moreover, this will indicate whether the results are robust for omitted variable bias.

The model is estimated including all control variables from the previous section and a term for unobserved heterogeneity (UHG), assuming normal distribution of the UHG component (see Appendix Table A7 and Fig. 7). As is shown in Fig. 7, the duration dependence gets more positive including the UHG component.

$<$ Fig. 7 about here $>$

This result is expected; the UHG component controls for that the sample is getting more selected with the unemployment duration, i.e. less employable individuals are still unemployed after some time $t$. Further, this is in line with search theory discussed in 
section 3. Hence, there is a positively selected sample of individuals exiting unemployment. The term for unobserved heterogeneity is significant and positive. Moreover, to include a term for unobserved heterogeneity shows that the direction and significant levels of the estimates are stable. However, most estimates get larger.

It is possible that the same factors that affect the probability of unemployment will influence the unemployment duration, i.e. the outcome in the probit model may affect the outcome in the hazard model. By estimating the two models simultaneously it is possible to examine the role of entry selection into unemployment for the estimated effects in the duration model (see Appendix Table A7). ${ }^{33}$ In the probit model, graduation years are grouped together as 1991-1993, 1994-1996 and 1997-1999. The reason is to get the model to converge. Control variables for observable characteristics are included in the models, as well as components for unobserved heterogeneity (omitted variables). Further a new term, Rho, is included. Rho measures the correlation between the two UHG components.

The UHG component is significant also in the probit model (sigma 2), but the inclusion does not change the significance or the direction of the estimates. However, the estimated effects are now much stronger, the size of the estimates about doubles for most of the estimates. Further, the result suggests that there is no significant correlation between the UHG in the two models, implying that it is not the same unobserved characteristics influencing the risk of unemployment and the unemployment duration.

\footnotetext{
${ }^{33}$ In this case only the individuals included in the hazard are included in the probit model. The result for the probit model using this sample is presented in Appendix Table A10.
} 
Moreover, the results for the hazard model are stable indicating there is no obvious entry selection. These results imply that there seems to be no systematic differences in the unobserved characteristics in the selection into unemployment that will influence the unemployment duration, suggesting there is no selection due to the risk of unemployment that will bias the results in the hazard model; the estimates for graduation years are robust.

\section{Conclusions}

The results in this paper show that the risk of getting unemployed at graduation and the unemployment duration vary considerably both within and across graduation years. The variation across years can not be explained by observable covariates. Consequently, there is no evidence of selection into or out of university studies across years.

Theoretically, there are many explanations for variation across time and over the business cycle. First, the demand for highly educated is likely to be of importance. Previous studies suggests that the demand for highly educated varies with the business cycle and has increased across time. An increased demand means more job offers. Second, the reservation wage may or may not adjust properly to variations over time. Third, search activity is also likely to affect both the risk of unemployment and the unemployment duration.

The estimated effect of different covariates varies across time. There is some variation in field of education consistent with the business cycle fluctuations; field of education 
matters more for the risk of unemployment and the unemployment duration during recessions. In general, there are no trends over time. The one exception is the relative decreasing trend in the risk of unemployment and the risk of exiting unemployment across time for individuals with the highest level degree. This indicates that the increased supply of more highly educated individuals has not posed a problem of finding a job, but for those who don't the unemployment is a more long lasting problem.

\section{Acknowledgments}

Financial support and data from IFAU (Institute for Labour Market Policy Evaluation) is gratefully acknowledged. I am grateful for valuable comments from Gunnar Andersson, Mahmood Arai, Thomas Lindh, Håkan Regnér, Oskar Nordström Skans, an anonymous referee and seminar participants at SUDSWEc 2007, Institute for Futures Studies 2007, IFAU 2008 and ESPE 2008. 


\section{References}

Albrecht J., Holmlund B. and Lang H. (1989) Job search and youth unemployment. Analyses of Swedish data, European Economic Review, 33, 416-425.

Andersson B. (2000) Growth, saving, and demography, PhD-thesis, Economic studies 52, Department of Economics, Uppsala University.

Betts J., Ferrall C. and Finnie R. (2000) The transition to work for Canadian university graduates: time to first job, 1982-1990, Analytical Studies Branch Research Paper Series 2000141e, Statistics Canada.

Blossfeld H-P. and Rohwer G. (2002) Techniques of event history modelling: new approaches to causal analysis, $2^{\text {nd }}$ editon. Mawah, Lawrence Erlbaum Associates, New Jersey.

Carling K., Edin P-A., Holmlund B. and Jansson F. (1996) Unemployment duration, unemployment benefits and labor market programmes in Sweden, Journal of Public Economics, 59, 313-334.

Edin P-A. and Gustavsson M. (2008) Time out of work and skill depreciation, Industrial and Labor Relations Rewiew, 62, 169-180.

Edin P-A. and Holmlund B. (1991) Unemployment, vacancies and labour market programmes: Swedish evidence, In Schioppa, F.P. (ed.), Mismatch and Labour Mobility. Cambridge University Press, Cambridge.

Edin P-A. (1989) Unemployment duration and competing risks: evidence from Sweden, Scandinavian Journal of Economics, 91, 639-653.

Gartell M. (2009) Unemployment and subsequent earnings for Swedish college graduates, Phd-thesis. Dissertation in Economics 2009:6, Economics Department, Stockholm University.

Gartell M. (2010) The college-to-work transition during the 1990s. Evidence from Sweden, Working paper 2010:3, Institute for Futures Studies, Stockholm.

Gartell M. and Regnèr H. (2005) Sambandet mellan val av högskola och inkomster efter examen för kvinnor och män (college choice and subsequent earnings for women and men) (In Swedish), Report 2005:12, Institute for Labour Market Policy Evaluation (IFAU), Uppsala.

Gartell M., Jans, A-C. and Persson, H. (2010) The importance of education for the reallocation of labor: evidence from Swedish linked employer-employee data 19862002, Labour Economics, 17, 206-214. 
Granqvist L. and Regnér H. (2007) Globaliseringen och akademikers arbetsmarknad (The globalization and labour market conditions for highly educated) (In Swedish), The Swedish Confederation of Professional Associations (SACO), Stockholm.

Harkman A. (1987) Arbetslös ungdom (Unemployed youth) (In Swedish), Allmänna förlaget, Stockholm, Sweden.

Holmlund B., Liu Q. and Nordström Skans O. (2006) Mind the gap? Estimating the effects of postponing higher education, CESifo Working Paper Series 1792, CESifo Group Munich.

Höjgård S. (1994) Long-term unemployment in a full employment economy, PhDthesis, Lund Economic Studies 57, Economics Department, Lund University, Lund.

The Swedish Unemployment Insurance Board (IAF), Fakta-PM 3:2005 (In Swedish).

Jans A-C. (2002) Notification and job losses on the Swedish labour market, Phd-thesis 54. Swedish institute for social research, Stockholm University, Stockholm.

Kettunen J. (1994) The effects of education on the duration on unemployment, Labour, 2, 331-352.

Kettunen J. (1997) Education and unemployment duration, Economics of Education Review, 16, 163-170.

Korpi T. (1995) Effects of manpower policies on duration dependence in reemployment rates: the example of Sweden, Economica, 62, 353-371.

Lancaster T. (1979) Econometric methods for the duration of unemployment, Econometrica, 47, 939-956.

Lillard L. A. and Panis C. W. A. (2003) aML users guide and reference manual, version 2, Econ Ware, Los Angeles.

National Agency for Higher Education (2001) Swedish universities and university colleges, Annual report.

National Agency for Higher Education (2007) The Swedish higher education system, HsvFs 2007:5, Stockholm, National Agency for Higher education.

National Agency for Higher Education (2006) OECD thematic review of tertiary education. Country background report for Sweden, Report Series 2006:41R, National Agency for Higher Education, Stockholm.

National Agency for Higher Education (2005) Higher education. Throughput and result in undergraduate education up to 2003/2004. National Agency for Higher Education, Stockholm. 
National Agency for Higher Education (2004) Swedish higher education. A survey 1977-2000, National Agency for Higher Education, Stockholm.

Nordström Skans O. (2005) Age effects in Swedish local labor markets, Economic Letters, 86, 419-426.

Nordström Skans O. (2004) Scarring effects of the first labour market experience: a sibiling based analysis, Working Paper 2004:14, Institute for Labour Market Policy Evaluation (IFAU), Uppsala.

Oreopoulos P., von Wachter T. and Heisz A. (2008) The short- and long-term career effects of graduation in a recession: hysteresis and heterogeneity in the market for college graduates, Discussion Paper No. 3578, Institute for the Study of Labor (IZA), Bonn.

Regnér H. and Gartell M. (2002) Arbetsmarknaden för högskoleutbildade. Inkomstutveckling och geografisk rörlighet under 1990-talet (The labour market for college graduates. Earnings and geographical mobility in the 1990s) (In Swedish), The Swedish Confederation of Professional Associations (SACO).

Statistics Sweden (1993) Studie av arbetslösa enligt AMV och enligt SCB (A studie of unemployed) (In Swedish), Bakgrundsfakta till arbetsmarknads- och utbildningsstatistiken, Statistics Sweden, Stockholm.

Stevens K. (2007) Adult labour market outcomes: the role of economic conditions at entry into the labour market, Preliminary version March 22 2007, University College London.

Swedish National Labour Market Board (1998) Arbetsförmedlingens marknadsandelar (The market shares of the public employment service), Uin98:3, Swedish National Labour Market board, Stockholm.

Thoursie A. (1998) Transitions from unemployment to employment: what are the effects of education?, Phd-thesis 35, Swedish Institute for Social Research, Stockholm University, Stockholm.

van der Klaauw B., van Vuuren A., and Berkhout P. (2005) Labor market prospects, search intensity and the transition from college to work, Working Paper 2005:9, Institute for Labour Market Policy Evaluation (IFAU), Uppsala. 


\section{Figures}

Fig. 1. Unemployment rates $1990-2003$ (per cent)

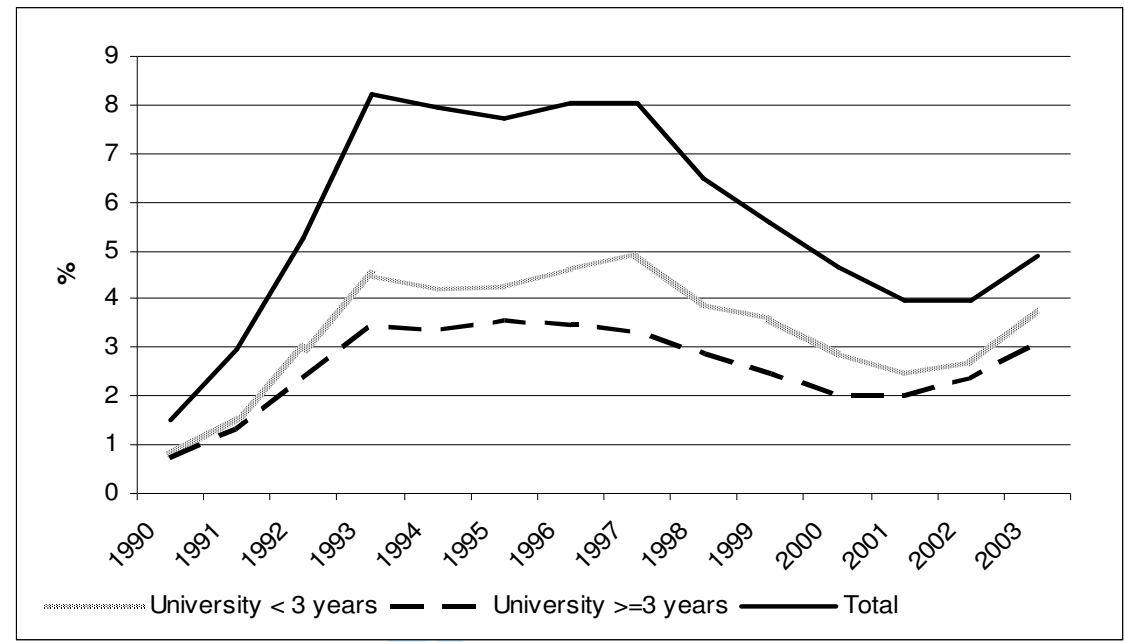

Source: Swedish Labour Force Survey

Fig. 2. Net employment rates 1989-2002 (percent)

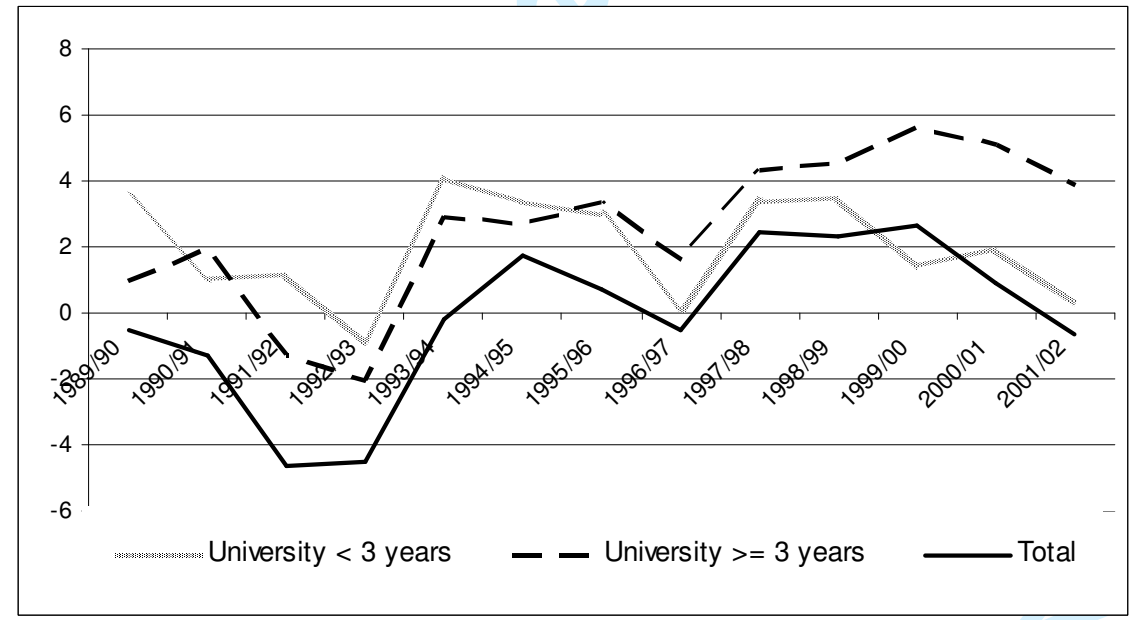

Source: Gartell et al. (2010) 
Fig. 3: Number of individuals born in different years in Sweden.

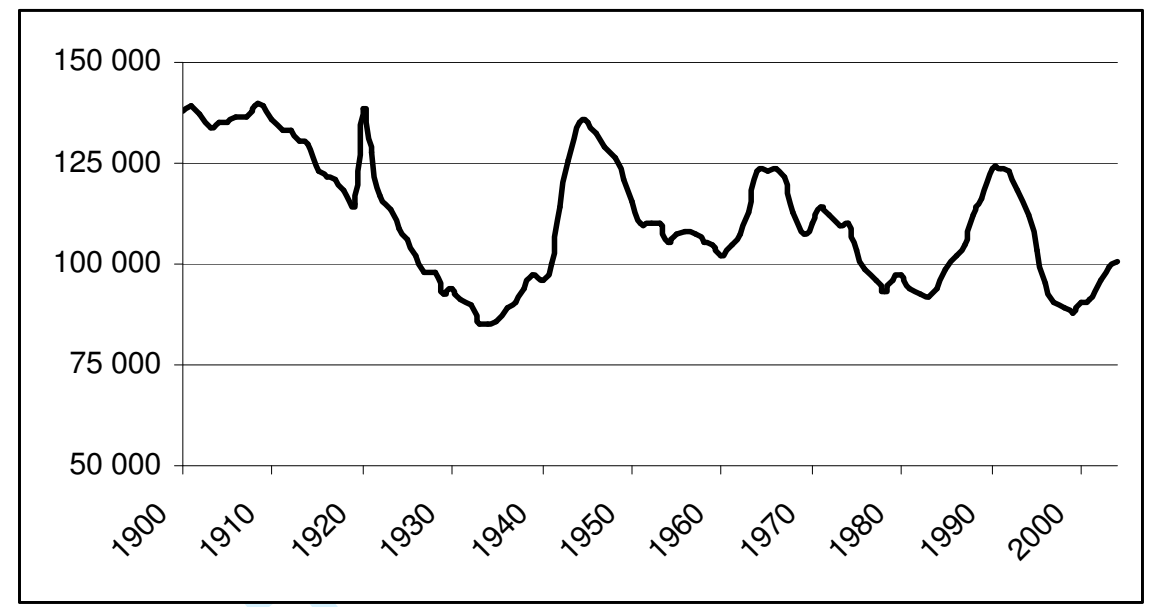

Source: Statistics Sweden

Fig. 4. Estimated marginal effects and confidence interval of the risk of unemployment

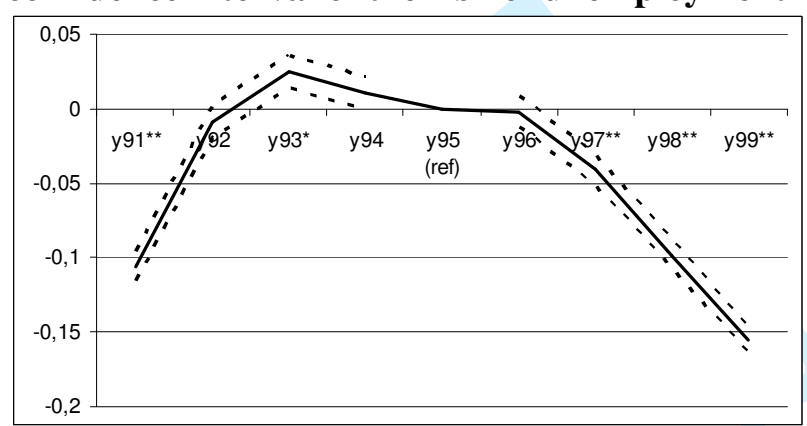

Notes: 1995 is the reference. Discrete changes. Robust SE. *significant at 5\%, ** significant at $1 \%$.

No control variables are included.

Fig. 5. Estimated risk and confidence interval of exiting unemployment

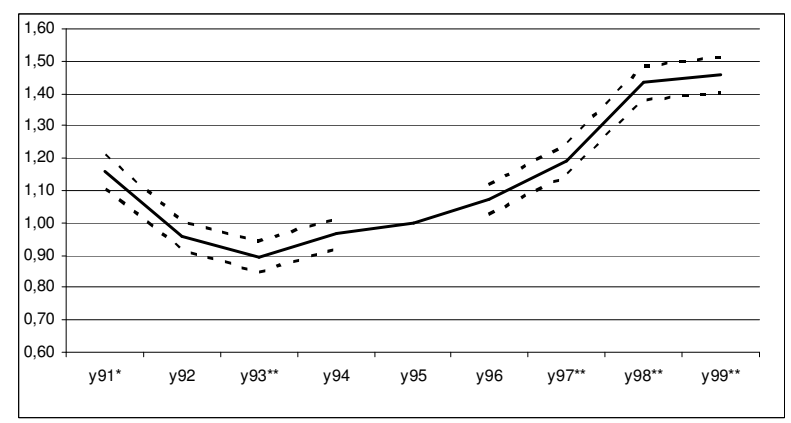

Notes: 1995 is the reference. The risk is presented i.e. exp(coeff). Robust SE. *significant at 5\%,** significant at $1 \%$. No control variables are included. 
Fig. 6. Log hazard baseline of exiting unemployment (month)

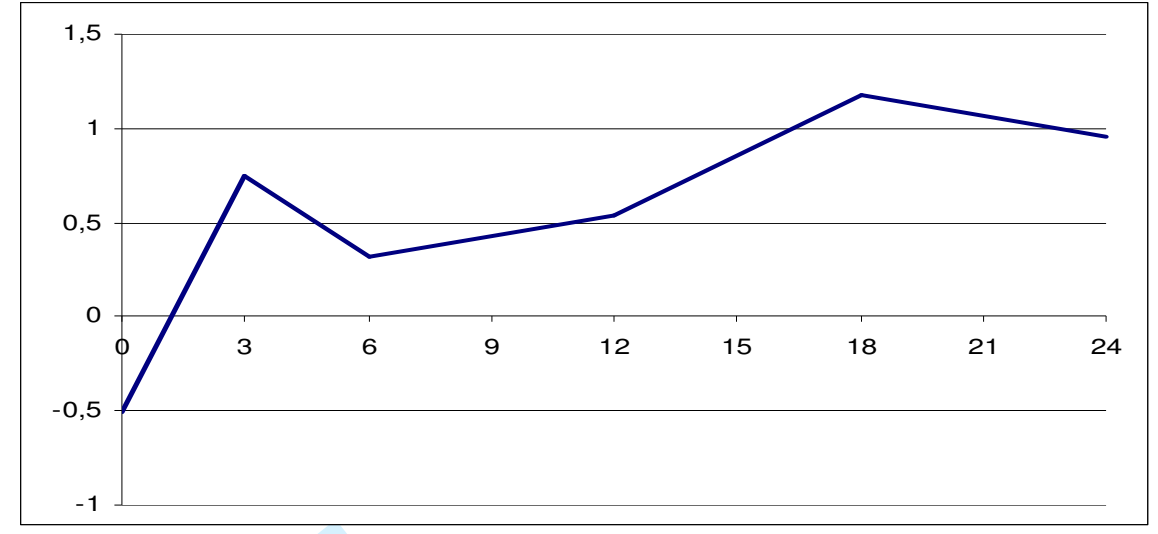

Notes: No control variables are included.

Fig. 7 Log hazard baseline of exiting unemployment, excluding and including unobserved heterogeneity (month)

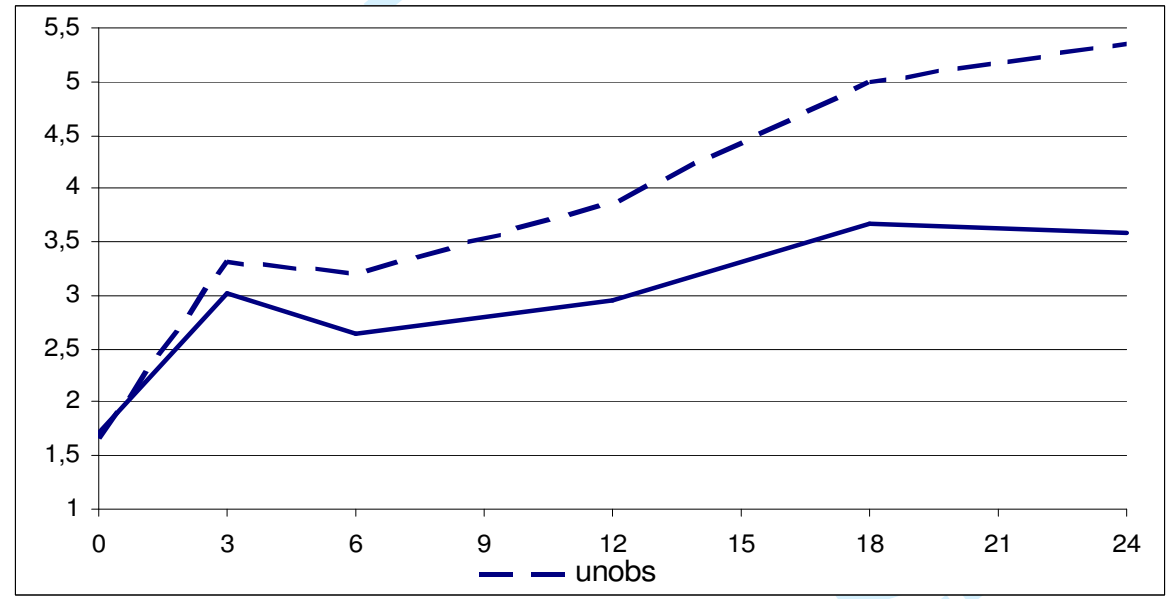

\section{Tables}

Table 1. Descriptives

\begin{tabular}{lll}
\hline Exam Year & $\begin{array}{l}\text { Number of } \\
\text { graduates }\end{array}$ & $\begin{array}{l}\text { Share of students that experienced any } \\
\text { unemployment at graduation }\end{array}$ \\
\hline 1991 & 3253 & 0.32 \\
1992 & 3422 & 0.42 \\
1993 & 3507 & 0.46 \\
1994 & 4083 & 0.44 \\
1995 & 4404 & 0.43 \\
1996 & 4492 & 0.43 \\
1997 & 4543 & 0.39 \\
1998 & 5066 & 0.33 \\
1999 & 5243 & 0.27 \\
\hline Tot & 38013 & 0.39 \\
\hline
\end{tabular}


Appendix

Table A1. Duration months, percentiles

\begin{tabular}{lllllll}
\hline & $\mathbf{5}$ & $\mathbf{2 5}$ & $\mathbf{5 0}$ & $\mathbf{7 5}$ & $\mathbf{9 5}$ & Nbr of obs \\
\hline $\mathbf{1 9 9 1}$ & 0.7 & 2.4 & 4.9 & 9.7 & 17.8 & 575 \\
$\mathbf{1 9 9 2}$ & 1.0 & 3.4 & 6.6 & 11.4 & 18.7 & 859 \\
$\mathbf{1 9 9 3}$ & 0.8 & 3.4 & 6.7 & 12.1 & 20.2 & 792 \\
$\mathbf{1 9 9 4}$ & 1.1 & 3.0 & 6.1 & 11.8 & 19.4 & 943 \\
$\mathbf{1 9 9 5}$ & 1.0 & 3.0 & 6.0 & 10.8 & 19.2 & 971 \\
$\mathbf{1 9 9 6}$ & 1.0 & 2.9 & 5.3 & 10.7 & 18.1 & 901 \\
$\mathbf{1 9 9 7}$ & 0.7 & 2.5 & 4.4 & 9.8 & 17.4 & 822 \\
$\mathbf{1 9 9 8}$ & 0.6 & 2.0 & 3.8 & 7.8 & 15.7 & 739 \\
$\mathbf{1 9 9 9}$ & 0.6 & 2.0 & 4.1 & 7.8 & 15.5 & 686 \\
\hline Good & 0.7 & 2.3 & 4.2 & 8.8 & 16.8 & 2822 \\
Bad & 1.0 & 3.1 & 6.1 & 11.4 & 19.1 & 4466 \\
\hline All & 0.8 & 2.8 & 5.3 & 10.3 & 18.4 & 7288 \\
\hline
\end{tabular}

Fig. A1. Unemployment duration

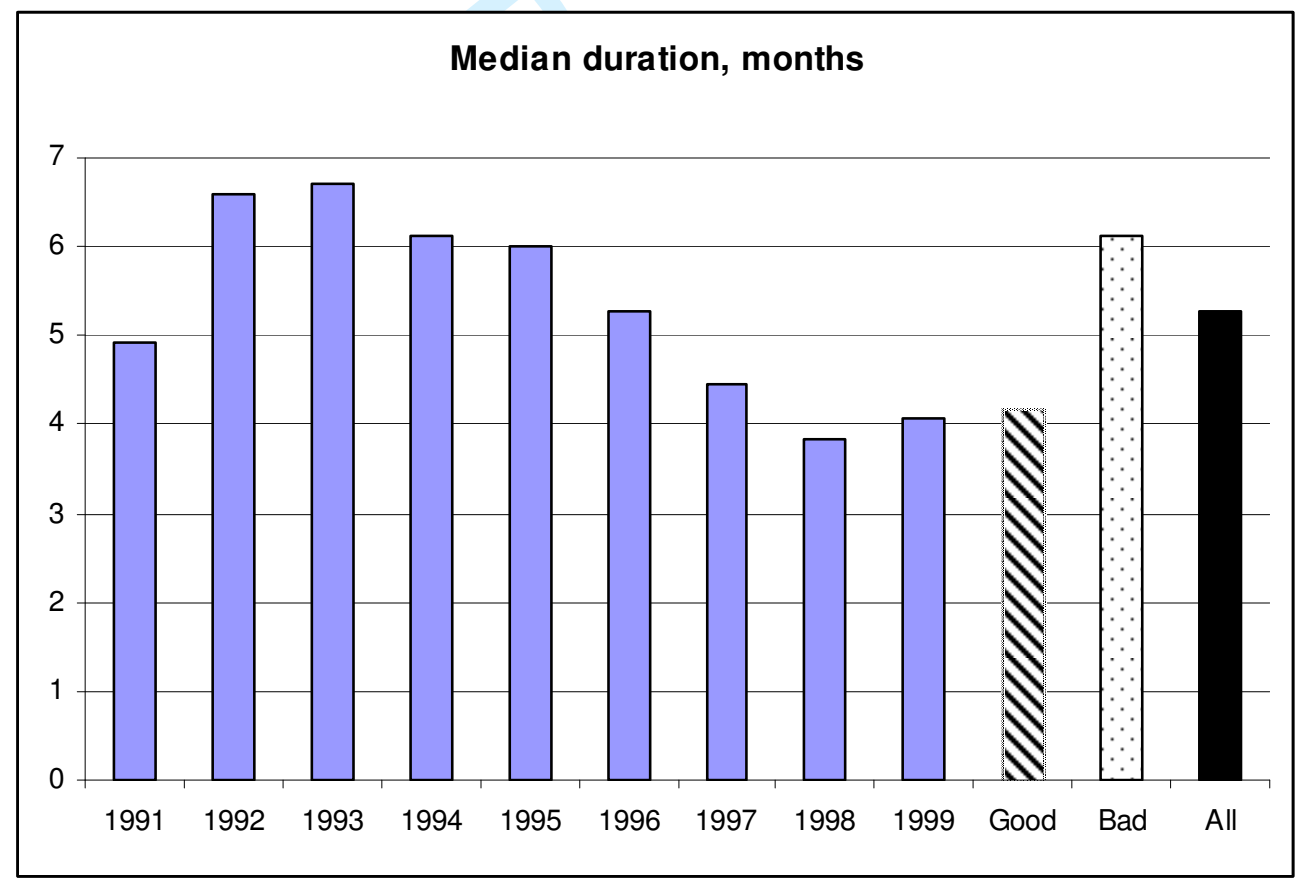


Table A2. Variable list

\begin{tabular}{|c|c|}
\hline Variables & Description \\
\hline Spring & Dummy variable $=1$ if graduated during spring semester (Jan 20- Aug 30) \\
\hline Women & Dummy variable $=1$ If a woman \\
\hline Age & Age at year of graduation \\
\hline $\mathrm{Age}^{\wedge} 2$ & Age squared \\
\hline Swe & Dummy variable, Born in Sweden $=1$ \\
\hline Nordic and W eu & Born in the Nordic countries or western Europe (Reference) \\
\hline Outside W eu & Dummy variable, Born outside Western Europe $=1$ \\
\hline Child y1 & Dummy variable, Had a child during first year after graduation $=1$ \\
\hline Child 0-3y & Dummy variable, Have child/children between the age $0-3$ years \\
\hline Child 3-6y & Dummy variable, Have child/children between the age 3-6 years \\
\hline Child 7-10y & Dummy variable, Have child/children between the age $7-10$ years \\
\hline Child $11-15$ y & Dummy variable, Have child/children between the age $11-15$ years \\
\hline Child $16-17 \mathrm{y}$ & Dummy variable, Have child/children between the age $16-17$ years \\
\hline Teacher & Dummy variable, field of education; teacher $=1$ \\
\hline Hum & Dummy variable, field of education; humaniora $=1$ \\
\hline Science & Dummy variable, field of education; natural science $=1$ \\
\hline Social science & Dummy variable, field of education; social science $=1$ (Reference) \\
\hline Technology & Dummy variable, field of education; technology $=1$ \\
\hline Healthcare & Dummy variable, field of education; health care $=1$ \\
\hline Service & Dummy variable, field of education; service/tourism=1 \\
\hline Educ $<3$ y & Dummy variable, education less than 3 years at least two $=1$ \\
\hline Educ 3 y & Dummy variable, education less than 4 years but at least 3 years $=1$ (Reference) \\
\hline Educ $>3$ y & Dummy variable, education 4 years or more $=1$ \\
\hline$M<$ high sch & Dummy variable, mothers education less than high school $=1$ \\
\hline M high sch & Dummy variable, mothers education high school $=1$ (Reference) \\
\hline M univ & Dummy variable, mothers education university $=1$ \\
\hline M unknown & Dummy variable, mothers education unknown $=1$ \\
\hline $\mathrm{F}<$ high sch & Dummy variable, fathers education less than high school $=1$ \\
\hline $\mathrm{F}$ high sch & Dummy variable, fathers education high school $=1$ (Reference) \\
\hline F univ & Dummy variable, fathers education university $=1$ \\
\hline F unknown & Dummy variable, fathers education unknown $=1$ \\
\hline Unemp & Continuous variable, unemployment rates for highly educated \\
\hline Akassa & Type of benefit; Akassa=1 (Reference) \\
\hline Kas & Type of benefit; kas=1 \\
\hline Noinfo & Type of benefit; no info about type of benefit=1 \\
\hline Unemp grad & Dummy variable, unemployment at graduation $=1$ \\
\hline First reg univ & Year of first registration in higher education \\
\hline
\end{tabular}

Table A3. Mean and SD for the samples

\begin{tabular}{llllllllll}
\hline & $\mathbf{1 9 9 1}$ & $\mathbf{1 9 9 2}$ & $\mathbf{1 9 9 3}$ & $\mathbf{1 9 9 4}$ & $\mathbf{1 9 9 5}$ & $\mathbf{1 9 9 6}$ & $\mathbf{1 9 9 7}$ & $\mathbf{1 9 9 8}$ & $\mathbf{1 9 9 9}$ \\
\hline Unemp grad & 0.32 & 0.42 & 0.46 & 0.44 & 0.43 & 0.43 & 0.39 & 0.33 & 0.27 \\
Unemp grad & 0.21 & 0.30 & 0.29 & 0.29 & 0.28 & 0.26 & 0.23 & 0.18 & 0.15 \\
Spring & 0.66 & 0.67 & 0.67 & 0.67 & 0.67 & 0.67 & 0.66 & 0.67 & 0.66 \\
Woman & 0.60 & 0.61 & 0.62 & 0.60 & 0.59 & 0.60 & 0.61 & 0.61 & 0.62 \\
Age & 30.10 & 30.38 & 30.20 & 30.33 & 30.25 & 29.86 & 29.82 & 29.79 & 30.12 \\
Age2 & 958.74 & 972.52 & 960.85 & 971.18 & 965.27 & 938.15 & 937.02 & 932.05 & 954.61 \\
Swe & 0.93 & 0.92 & 0.92 & 0.92 & 0.92 & 0.91 & 0.92 & 0.90 & 0.90 \\
Nordig 6 W eu & 0.04 & 0.04 & 0.04 & 0.04 & 0.03 & 0.03 & 0.03 & 0.03 & 0.03 \\
Outside W eu & 0.04 & 0.04 & 0.05 & 0.05 & 0.05 & 0.06 & 0.05 & 0.06 & 0.07 \\
Child y1 & 0.04 & 0.04 & 0.04 & 0.04 & 0.04 & 0.03 & 0.03 & 0.03 & 0.03 \\
Child 0-3y & 0.09 & 0.09 & 0.10 & 0.09 & 0.09 & 0.09 & 0.08 & 0.08 & 0.08 \\
Child 4-6y & 0.05 & 0.05 & 0.06 & 0.05 & 0.06 & 0.06 & 0.06 & 0.06 & 0.06 \\
Child 7-10y & 0.06 & 0.07 & 0.06 & 0.06 & 0.06 & 0.06 & 0.06 & 0.06 & 0.06 \\
Child 11-15y & 0.26 & 0.27 & 0.25 & 0.26 & 0.25 & 0.25 & 0.23 & 0.24 & 0.23 \\
Child 16-17y & 0.21 & 0.19 & 0.19 & 0.19 & 0.18 & 0.17 & 0.16 & 0.17 & 0.16 \\
Teacher & 0.06 & 0.09 & 0.11 & 0.10 & 0.09 & 0.10 & 0.08 & 0.09 & 0.09 \\
Hum & 0.09 & 0.09 & 0.09 & 0.10 & 0.14 & 0.13 & 0.14 & 0.13 & 0.13
\end{tabular}




\begin{tabular}{llllllllll} 
Science & 0.12 & 0.11 & 0.10 & 0.11 & 0.12 & 0.13 & 0.12 & 0.12 & 0.14 \\
Social science & 0.53 & 0.51 & 0.50 & 0.51 & 0.48 & 0.47 & 0.46 & 0.43 & 0.42 \\
Thechnology & 0.03 & 0.03 & 0.03 & 0.04 & 0.03 & 0.04 & 0.04 & 0.04 & 0.04 \\
Healthcare & 0.17 & 0.17 & 0.17 & 0.15 & 0.15 & 0.13 & 0.14 & 0.17 & 0.17 \\
Service & 0.00 & 0.01 & 0.00 & 0.00 & 0.00 & 0.01 & 0.01 & 0.01 & 0.01 \\
Educ<3y & 0.10 & 0.13 & 0.11 & 0.10 & 0.09 & 0.07 & 0.06 & 0.05 & 0.04 \\
Educ= 3y & 0.61 & 0.57 & 0.55 & 0.49 & 0.47 & 0.48 & 0.43 & 0.43 & 0.41 \\
Educ >3y & 0.29 & 0.30 & 0.35 & 0.41 & 0.44 & 0.45 & 0.51 & 0.52 & 0.55 \\
M< high sch & 0.35 & 0.34 & 0.31 & 0.30 & 0.26 & 0.26 & 0.24 & 0.23 & 0.21 \\
M high sch & 0.18 & 0.18 & 0.18 & 0.19 & 0.19 & 0.20 & 0.22 & 0.23 & 0.23 \\
M univ & 0.46 & 0.48 & 0.51 & 0.51 & 0.54 & 0.55 & 0.55 & 0.55 & 0.55 \\
M unknown & 0.02 & 0.02 & 0.03 & 0.02 & 0.03 & 0.03 & 0.03 & 0.03 & 0.03 \\
F< high sch & 0.32 & 0.32 & 0.29 & 0.28 & 0.26 & 0.25 & 0.23 & 0.23 & 0.22 \\
F high sch & 0.15 & 0.16 & 0.16 & 0.17 & 0.16 & 0.17 & 0.20 & 0.20 & 0.21 \\
F univ & 0.52 & 0.53 & 0.55 & 0.55 & 0.57 & 0.58 & 0.57 & 0.57 & 0.57 \\
F unknown & 0.02 & 0.02 & 0.03 & 0.03 & 0.03 & 0.03 & 0.04 & 0.03 & 0.04 \\
Average grade & 4.03 & 3.95 & 3.93 & 3.92 & 3.89 & 3.87 & 3.87 & 3.86 & 3.85 \\
Kas & 0.03 & 0.05 & 0.12 & 0.11 & 0.11 & 0.11 & 0.08 & 0.07 & 0.09 \\
Akassa & 0.22 & 0.25 & 0.28 & 0.31 & 0.30 & 0.32 & 0.32 & 0.31 & 0.27 \\
Noinfo & 0.19 & 0.21 & 0.15 & 0.13 & 0.13 & 0.13 & 0.13 & 0.11 & 0.10 \\
Unemp & 1.50 & 2.70 & 4.00 & 3.80 & 3.90 & 4.10 & 4.30 & 3.50 & 3.10 \\
First reg univ & 1984.81 & 1985.55 & 1986.52 & 1987.25 & 1988.03 & 1989.01 & 1989.91 & 1990.81 & 1991.47 \\
Obs & 3253 & 3422 & 3507 & 4083 & 4404 & 4492 & 4543 & 5066 & 5243 \\
\hline
\end{tabular}

Table A4. Probability of getting unemployed at graduation, and the risk of exiting unemployment.

\begin{tabular}{|c|c|c|c|c|c|c|}
\hline \multirow{2}{*}{ y91 } & \multicolumn{4}{|c|}{$\begin{array}{l}\text { Probit model: the probability of getting unemployed } \\
\text { at graduation }\end{array}$} & \multicolumn{2}{|c|}{$\begin{array}{l}\text { Hazard model: the risk of exiting } \\
\text { unemployment if unemployed at araduation }\end{array}$} \\
\hline & $-0.106^{* \star}$ & $-0.106^{\star *}$ & $-0.099^{\star *}$ & $-0.101^{\star *}$ & $1.157^{\star \star}$ & 1.103 \\
\hline & $(0.010)$ & $(0.010)$ & $(0.010)$ & $(0.010)$ & $(0.054)$ & $(0.055)$ \\
\hline \multirow[t]{2}{*}{ y92 } & -0.009 & -0.008 & 0.002 & 0.001 & 0.960 & 0.920 \\
\hline & $(0.011)$ & $(0.011)$ & $(0.011)$ & $(0.011)$ & $(0.045)$ & $(0.047)$ \\
\hline \multirow[t]{2}{*}{ y93 } & $0.025^{*}$ & $0.024^{*}$ & $0.029^{\star *}$ & $0.029^{\star \star}$ & $0.895^{\star}$ & $0.863^{* *}$ \\
\hline & $(0.011)$ & $(0.011)$ & $(0.011)$ & $(0.011)$ & $(0.0489$ & $(0.048)$ \\
\hline \multirow[t]{2}{*}{ y94 } & 0.011 & 0.012 & 0.014 & 0.014 & 0.966 & 0.974 \\
\hline & $(0.011)$ & $(0.011)$ & $(0.011)$ & $(0.011)$ & $(0.045)$ & $(0.045)$ \\
\hline \multirow[t]{2}{*}{ y96 } & -0.002 & -0.006 & -0.007 & -0.007 & 1.074 & 1.070 \\
\hline & $(0.010)$ & $(0.010)$ & $(0.010)$ & $(0.010)$ & $(0.0469$ & $(0.046)$ \\
\hline \multirow[t]{2}{*}{ y97 } & $-0.041^{\star *}$ & $-0.046^{* *}$ & $-0.049^{* *}$ & $-0.049^{* *}$ & $1.192^{\star *}$ & $1.189^{\star *}$ \\
\hline & $(0.010)$ & $(0.010)$ & $(0.010)$ & $(0.010)$ & $(0.048)$ & $(0.048)$ \\
\hline \multirow[t]{2}{*}{ y98 } & $-0.098^{* *}$ & $-0.104^{* *}$ & $-0.106^{\star *}$ & $-0.106^{\star *}$ & $1.434^{* *}$ & $1.428^{* *}$ \\
\hline & $(0.009)$ & $(0.009)$ & $(0.009)$ & $(0.009)$ & (0.052) & $(0.052)$ \\
\hline \multirow[t]{2}{*}{ y99 } & $-0.155^{\star *}$ & $-0.162^{\star *}$ & $-0.162^{\star *}$ & $-0.162^{\star *}$ & $1.458^{* *}$ & $1.497^{* *}$ \\
\hline & $(0.009)$ & $(0.009)$ & $(0.009)$ & $(0.009)$ & $(0.053)$ & $(0.053)$ \\
\hline \multirow[t]{2}{*}{ Spring } & & $-0.076^{\star *}$ & $-0.073^{\star *}$ & $-0.074^{\star *}$ & & $0.833^{* *}$ \\
\hline & & $(0.005)$ & $(0.005)$ & $(0.005)$ & & $(0.025)$ \\
\hline \multirow[t]{2}{*}{ Women } & & $0.052^{* *}$ & $0.051^{* *}$ & $0.051^{* *}$ & & 0.998 \\
\hline & & $(0.005)$ & $(0.005)$ & $(0.005)$ & & $(0.025)$ \\
\hline \multirow[t]{2}{*}{ Age } & & $0.035^{\star *}$ & $0.026^{* *}$ & $0.025^{* *}$ & & $0.902^{* *}$ \\
\hline & & $(0.003)$ & $(0.003)$ & $(0.003)$ & & $(0.018)$ \\
\hline \multirow[t]{2}{*}{ Age2 } & & $-0.001^{* *}$ & $-0.000^{* *}$ & $-0.000^{* *}$ & & $1.001^{* *}$ \\
\hline & & $(0.000)$ & $(0.000)$ & $(0.000)$ & & $(0.000)$ \\
\hline \multirow[t]{2}{*}{ Swe } & & $-0.047^{* *}$ & $-0.040^{* *}$ & $-0.047^{* *}$ & & $1.125^{*}$ \\
\hline & & $(0.014)$ & $(0.014)$ & $(0.015)$ & & $(0.058)$ \\
\hline \multirow[t]{2}{*}{ Outside W eu } & & $0.063^{* *}$ & $0.088^{\star *}$ & $0.089^{\star \star}$ & & 0.880 \\
\hline & & $(0.018)$ & $(0.019)$ & $(0.019)$ & & $(0.072)$ \\
\hline
\end{tabular}


Child 0-3y

$-0.027^{\star *} \quad-0.032^{\star *}$

$\begin{array}{lll}(0.009) & (0.009) & (0.009)\end{array}$

Child 4-6y

0.000

0.008

0.008

Child 7-10y

$(0.012)$

(0.012) (0.012)

$\begin{array}{lll}-0.024^{*} & -0.008 & -0.009\end{array}$

Child 11-15y

$(0.012)$

(0.012) (0.012)

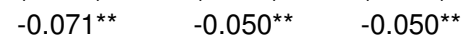

$\begin{array}{lll}(0.011) & (0.011) & (0.011)\end{array}$

Child 16-17y

$$
-0.043^{* *}
$$

$-0.024$

(0.015)

$-0.024$

Teacher

0.003

(0.009)

$(0.015)$

Hum

Science

(0.008) (0.008)

$-0.155^{\star *} \quad-0.156^{\star *}$

(0.007) (0.007)

Technology

$-0.163^{\text {** }}$

$-0.163^{* *}$

(0.012)

$(0.012)$

Healthcare

$-0.112^{* *}$

$-0.113^{* *}$

(0.008)

(0.008)

Service

$0.160^{\text {** }}$

$0.159^{* *}$

(0.037) (0.037)

Educ $<3 y$

$-0.101^{* *}$

$-0.104^{\text {** }}$

(0.010)

(0.010)

Educ > 3y

$0.025^{\text {** }}$

$0.026^{* *}$

(0.005)

(0.005)

$-0.009$

(0.008)

$-0.010$

(0.007)

$-0.014$

(0.016)

$0.021^{* *}$

(0.008)

$-0.003$

(0.007)

$-0.005$

F unknown

(0.015)

3 month

-

6 month - -

12 month

18 month

24 month

Constant

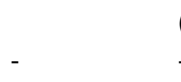

44

45

46

47

48

49

50

51

52

$$
\begin{aligned}
& 1.004 \\
& \text { (0.045) } \\
& 1.069 \\
& \text { (0.059) } \\
& 1.203^{* *} \\
& \text { (0.059) } \\
& 1.085 \\
& \text { (0.064) } \\
& 1.085 \\
& \text { (0.079) } \\
& 1.371^{* *} \\
& \text { (0.044) } \\
& 0.951 \\
& \text { (0.039) } \\
& 1.028 \\
& \text { (0.042) } \\
& 1.360^{* *} \\
& \text { (0.077) } \\
& 1.761^{\text {** }} \\
& \text { (0.046) } \\
& 0.938 \\
& \text { (0.165) } \\
& 0.893 \\
& \text { (0.069) } \\
& 1.101^{* *} \\
& \text { (0.026) } \\
& 0.978 \\
& \text { (0.037) } \\
& 1.035 \\
& \text { (0.032) } \\
& 0.927 \\
& \text { (0.078) } \\
& 0.988 \\
& \text { (0.038) } \\
& 1.023 \\
& \text { (0.034) } \\
& 0.966 \\
& \text { (0.073) } \\
& 5.227^{\text {** }} \\
& (0.243)-(0.242) \\
& \text { (0.185) (0.185) } \\
& \text { (0.106) (0.107) } \\
& \text { (0.142) (0.142) } \\
& \text { (0.308) (0.306) } \\
& \text { (0.054) (0.310) }
\end{aligned}
$$$$
-1.714^{\star *}-1.545^{\star *}
$$$$
0.450^{* *} \quad 0.603^{\star \star}
$$$$
1.271^{* *} \quad 1.455^{* *}
$$$$
-0.437 \quad-0.165
$$$$
0.599^{* *} \quad 2.859^{\star \star}
$$

$\begin{array}{llllllll}\text { Observations } & 38013 & 38013 & 38013 & 38013 & 7285 & 7285\end{array}$

Notes: Discrete changes. Robust SE in parenthesis. significant at 5\%, $* *$ significant at $1 \%$. References are; y95, Nordic and W eu, social science, $\mathrm{M}$ high sch, F high sch. 
Table A5. Probability of getting unemployed at graduation, across graduation years

\begin{tabular}{|c|c|c|c|c|c|c|c|c|c|}
\hline & 1991 & 1992 & 1993 & 1994 & 1995 & 1996 & 1997 & 1998 & 1999 \\
\hline Spring & $\begin{array}{l}-0.029 \\
(0.018)\end{array}$ & $\begin{array}{l}-0.069^{\star \star} \\
(0.019)\end{array}$ & $\begin{array}{l}-0.046^{\star} \\
(0.018)\end{array}$ & $\begin{array}{l}-0.064^{\star \star} \\
(0.017)\end{array}$ & $\begin{array}{l}-0.081^{\star *} \\
(0.016)\end{array}$ & $\begin{array}{l}-0.073^{\star \star} \\
(0.016)\end{array}$ & $\begin{array}{l}-0.099^{\star \star} \\
(0.016)\end{array}$ & $\begin{array}{l}-0.089^{\star \star} \\
(0.015)\end{array}$ & $\begin{array}{l}-0.080^{\star \star} \\
(0.014)\end{array}$ \\
\hline Women & $\begin{array}{l}0.012 \\
(0.018)\end{array}$ & $\begin{array}{l}0.040^{*} \\
(0.019)\end{array}$ & $\begin{array}{l}0.060^{* *} \\
(0.019)\end{array}$ & $\begin{array}{l}0.073^{* *} \\
(0.017)\end{array}$ & $\begin{array}{l}0.057^{* *} \\
(0.016)\end{array}$ & $\begin{array}{l}0.055^{\star *} \\
(0.016)\end{array}$ & $\begin{array}{l}0.048^{* *} \\
(0.016)\end{array}$ & $\begin{array}{l}0.073^{* *} \\
(0.014)\end{array}$ & $\begin{array}{l}0.033^{*} \\
(0.013)\end{array}$ \\
\hline Age & $\begin{array}{l}0.006 \\
(0.012)\end{array}$ & $\begin{array}{l}-0.022 \\
(0.012)\end{array}$ & $\begin{array}{l}-0.002 \\
(0.012)\end{array}$ & $\begin{array}{l}0.031^{* *} \\
(0.010)\end{array}$ & $\begin{array}{l}0.032^{* *} \\
(0.010)\end{array}$ & $\begin{array}{l}0.049^{* *} \\
(0.010)\end{array}$ & $\begin{array}{l}0.046^{* *} \\
(0.010)\end{array}$ & $\begin{array}{l}0.027^{\star *} \\
(0.008)\end{array}$ & $\begin{array}{l}0.034^{* *} \\
(0.007)\end{array}$ \\
\hline Age2 & $\begin{array}{l}-0.000 \\
(0.000)\end{array}$ & $\begin{array}{l}0.000 \\
(0.000)\end{array}$ & $\begin{array}{l}-0.000 \\
(0.000)\end{array}$ & $\begin{array}{l}-0.001^{\star \star} \\
(0.000)\end{array}$ & $\begin{array}{l}-0.001^{\star *} \\
(0.000)\end{array}$ & $\begin{array}{l}-0.001^{* *} \\
(0.000)\end{array}$ & $\begin{array}{l}-0.001^{\star *} \\
(0.000)\end{array}$ & $\begin{array}{l}-0.000^{\star \star} \\
(0.000)\end{array}$ & $\begin{array}{l}-0.000^{\star *} \\
(0.000)\end{array}$ \\
\hline Swe & $\begin{array}{l}-0.062 \\
(0.049)\end{array}$ & $\begin{array}{l}-0.110^{*} \\
(0.046)\end{array}$ & $\begin{array}{l}-0.111^{*} \\
(0.048)\end{array}$ & $\begin{array}{l}-0.019 \\
(0.043)\end{array}$ & $\begin{array}{l}-0.001 \\
(0.045)\end{array}$ & $\begin{array}{l}0.015 \\
(0.043)\end{array}$ & $\begin{array}{l}-0.112^{*} \\
(0.044)\end{array}$ & $\begin{array}{l}0.020 \\
(0.038)\end{array}$ & $\begin{array}{l}-0.061 \\
(0.037)\end{array}$ \\
\hline Outside W eu & $\begin{array}{l}0.047 \\
(0.066)\end{array}$ & $\begin{array}{l}0.033 \\
(0.064)\end{array}$ & $\begin{array}{l}0.041 \\
(0.062)\end{array}$ & $\begin{array}{l}0.131^{*} \\
(0.056)\end{array}$ & $\begin{array}{l}0.099 \\
(0.057)\end{array}$ & $\begin{array}{l}0.151^{\star *} \\
(0.053)\end{array}$ & $\begin{array}{l}-0.008 \\
(0.052)\end{array}$ & $\begin{array}{l}0.167^{\star *} \\
(0.050)\end{array}$ & $\begin{array}{l}0.079 \\
(0.045)\end{array}$ \\
\hline Child 0-3y & $\begin{array}{l}-0.011 \\
(0.031)\end{array}$ & $\begin{array}{l}-0.054 \\
(0.031)\end{array}$ & $\begin{array}{l}0.007 \\
(0.031)\end{array}$ & $\begin{array}{l}-0.026 \\
(0.030)\end{array}$ & $\begin{array}{l}-0.061^{*} \\
(0.027)\end{array}$ & $\begin{array}{l}-0.027 \\
(0.028)\end{array}$ & $\begin{array}{l}0.014 \\
(0.028)\end{array}$ & $\begin{array}{l}-0.046 \\
(0.025)\end{array}$ & $\begin{array}{l}-0.059^{* *} \\
(0.022)\end{array}$ \\
\hline Child 4-6y & $\begin{array}{l}-0.039 \\
(0.042)\end{array}$ & $\begin{array}{l}0.048 \\
(0.044)\end{array}$ & $\begin{array}{l}-0.002 \\
(0.040)\end{array}$ & $\begin{array}{l}-0.067 \\
(0.038)\end{array}$ & $\begin{array}{l}0.041 \\
(0.037)\end{array}$ & $\begin{array}{l}0.018 \\
(0.036)\end{array}$ & $\begin{array}{l}-0.021 \\
(0.034)\end{array}$ & $\begin{array}{l}0.027 \\
(0.032)\end{array}$ & $\begin{array}{l}0.012 \\
(0.029)\end{array}$ \\
\hline Child 7-10y & $\begin{array}{l}0.018 \\
(0.041)\end{array}$ & $\begin{array}{l}-0.014 \\
(0.039)\end{array}$ & $\begin{array}{l}-0.068 \\
(0.039)\end{array}$ & $\begin{array}{l}0.026 \\
(0.036)\end{array}$ & $\begin{array}{l}-0.011 \\
(0.037)\end{array}$ & $\begin{array}{l}-0.026 \\
(0.035)\end{array}$ & $\begin{array}{l}-0.005 \\
(0.036)\end{array}$ & $\begin{array}{l}-0.040 \\
(0.030)\end{array}$ & $\begin{array}{l}0.022 \\
(0.029)\end{array}$ \\
\hline Child 11-15y & $\begin{array}{l}-0.061 \\
(0.035)\end{array}$ & $\begin{array}{l}0.001 \\
(0.037)\end{array}$ & $\begin{array}{l}-0.046 \\
(0.038)\end{array}$ & $\begin{array}{l}-0.030 \\
(0.035)\end{array}$ & $\begin{array}{l}-0.052 \\
(0.035)\end{array}$ & $\begin{array}{l}-0.052 \\
(0.034)\end{array}$ & $\begin{array}{l}-0.069 \\
(0.035)\end{array}$ & $\begin{array}{l}-0.049 \\
(0.030)\end{array}$ & $\begin{array}{l}-0.064^{*} \\
(0.026)\end{array}$ \\
\hline Child 16-17y & $\begin{array}{l}-0.016 \\
(0.042)\end{array}$ & $\begin{array}{l}0.017 \\
(0.049)\end{array}$ & $\begin{array}{l}-0.023 \\
(0.048)\end{array}$ & $\begin{array}{l}-0.039 \\
(0.046)\end{array}$ & $\begin{array}{l}-0.077 \\
(0.044)\end{array}$ & $\begin{array}{l}0.008 \\
(0.048)\end{array}$ & $\begin{array}{l}0.078 \\
(0.051)\end{array}$ & $\begin{array}{l}-0.045 \\
(0.041)\end{array}$ & $\begin{array}{l}-0.046 \\
(0.037)\end{array}$ \\
\hline Teacher & $\begin{array}{l}0.180^{* *} \\
(0.039)\end{array}$ & $\begin{array}{l}0.100^{* *} \\
(0.034)\end{array}$ & $\begin{array}{l}0.015 \\
(0.029)\end{array}$ & $\begin{array}{l}-0.045 \\
(0.028)\end{array}$ & $\begin{array}{l}-0.062^{*} \\
(0.028)\end{array}$ & $\begin{array}{l}0.019 \\
(0.026)\end{array}$ & $\begin{array}{l}-0.008 \\
(0.028)\end{array}$ & $\begin{array}{l}-0.002 \\
(0.024)\end{array}$ & $\begin{array}{l}-0.014 \\
(0.022)\end{array}$ \\
\hline Hum & $\begin{array}{l}0.064^{*} \\
(0.032)\end{array}$ & $\begin{array}{l}-0.026 \\
(0.032)\end{array}$ & $\begin{array}{l}-0.102^{* *} \\
(0.030)\end{array}$ & $\begin{array}{l}-0.027 \\
(0.028)\end{array}$ & $\begin{array}{l}0.023 \\
(0.024)\end{array}$ & $\begin{array}{l}0.053^{*} \\
(0.024)\end{array}$ & $\begin{array}{l}0.003 \\
(0.023)\end{array}$ & $\begin{array}{l}0.128^{* *} \\
(0.022)\end{array}$ & $\begin{array}{l}0.089^{* *} \\
(0.021)\end{array}$ \\
\hline Science & $\begin{array}{l}-0.142^{* *} \\
(0.023)\end{array}$ & $\begin{array}{l}-0.194^{\star *} \\
(0.026)\end{array}$ & $\begin{array}{l}-0.200^{* *} \\
(0.026)\end{array}$ & $\begin{array}{l}-0.196^{\star *} \\
(0.023)\end{array}$ & $\begin{array}{l}-0.197^{\star *} \\
(0.022)\end{array}$ & $\begin{array}{l}-0.210^{* *} \\
(0.021)\end{array}$ & $\begin{array}{l}-0.147^{\star *} \\
(0.021)\end{array}$ & $\begin{array}{l}-0.092^{* *} \\
(0.020)\end{array}$ & $\begin{array}{l}-0.066^{* *} \\
(0.018)\end{array}$ \\
\hline Technology & $\begin{array}{l}-0.067 \\
(0.046)\end{array}$ & $\begin{array}{l}-0.099^{*} \\
(0.050)\end{array}$ & $\begin{array}{l}-0.121^{*} \\
(0.052)\end{array}$ & $\begin{array}{l}-0.222^{* *} \\
(0.038)\end{array}$ & $\begin{array}{l}-0.188^{* *} \\
(0.038)\end{array}$ & $\begin{array}{l}-0.253^{* *} \\
(0.032)\end{array}$ & $\begin{array}{l}-0.208^{\star *} \\
(0.031)\end{array}$ & $\begin{array}{l}-0.188^{\star *} \\
(0.026)\end{array}$ & $\begin{array}{l}-0.053 \\
(0.029)\end{array}$ \\
\hline Healthcare & $\begin{array}{l}-0.042 \\
(0.028)\end{array}$ & $\begin{array}{l}-0.112^{\star *} \\
(0.027)\end{array}$ & $\begin{array}{l}-0.143^{* *} \\
(0.028)\end{array}$ & $\begin{array}{l}-0.166^{\star *} \\
(0.026)\end{array}$ & $\begin{array}{l}-0.177^{* *} \\
(0.023)\end{array}$ & $\begin{array}{l}-0.121^{\text {**}} \\
(0.025)\end{array}$ & $\begin{array}{l}-0.085^{\star *} \\
(0.024)\end{array}$ & $\begin{array}{l}-0.062^{* *} \\
(0.020)\end{array}$ & $\begin{array}{l}-0.083^{\text {** }} \\
(0.017)\end{array}$ \\
\hline Service & $\begin{array}{l}0.181 \\
(0.150)\end{array}$ & $\begin{array}{l}-0.101 \\
(0.108)\end{array}$ & $\begin{array}{l}0.155 \\
(0.195)\end{array}$ & $\begin{array}{l}0.240 \\
(0.132)\end{array}$ & $\begin{array}{l}0.135 \\
(0.162)\end{array}$ & $\begin{array}{l}0.211^{*} \\
(0.100)\end{array}$ & $\begin{array}{l}0.227^{\star *} \\
(0.077)\end{array}$ & $\begin{array}{l}0.109 \\
(0.082)\end{array}$ & $\begin{array}{l}0.253^{* *} \\
(0.096)\end{array}$ \\
\hline Educ $<3 y$ & $\begin{array}{l}-0.075^{*} \\
(0.035)\end{array}$ & $\begin{array}{l}-0.146^{\star *} \\
(0.030)\end{array}$ & $\begin{array}{l}-0.088^{*} \\
(0.035)\end{array}$ & $\begin{array}{l}-0.157^{\star *} \\
(0.032)\end{array}$ & $\begin{array}{l}-0.125^{* *} \\
(0.031)\end{array}$ & $\begin{array}{l}-0.047 \\
(0.036)\end{array}$ & $\begin{array}{l}-0.106^{\star *} \\
(0.034)\end{array}$ & $\begin{array}{l}-0.096^{\star *} \\
(0.030)\end{array}$ & $\begin{array}{l}-0.039 \\
(0.031)\end{array}$ \\
\hline Educ> $>$ y & $\begin{array}{l}0.076^{* *} \\
(0.020)\end{array}$ & $\begin{array}{l}0.054^{* *} \\
(0.021)\end{array}$ & $\begin{array}{l}-0.032 \\
(0.019)\end{array}$ & $\begin{array}{l}0.034^{*} \\
(0.017)\end{array}$ & $\begin{array}{l}0.064^{* *} \\
(0.017)\end{array}$ & $\begin{array}{l}0.036^{*} \\
(0.016)\end{array}$ & $\begin{array}{l}0.001 \\
(0.016)\end{array}$ & $\begin{array}{l}0.014 \\
(0.014)\end{array}$ & $\begin{array}{l}0.012 \\
(0.013)\end{array}$ \\
\hline$M<$ high sch & $\begin{array}{l}0.026 \\
(0.025)\end{array}$ & $\begin{array}{l}0.007 \\
(0.026)\end{array}$ & $\begin{array}{l}0.005 \\
(0.027)\end{array}$ & $\begin{array}{l}0.054^{*} \\
(0.025)\end{array}$ & $\begin{array}{l}-0.022 \\
(0.024)\end{array}$ & $\begin{array}{l}-0.018 \\
(0.024)\end{array}$ & $\begin{array}{l}-0.036 \\
(0.023)\end{array}$ & $\begin{array}{l}-0.021 \\
(0.021)\end{array}$ & $\begin{array}{l}-0.037^{*} \\
(0.019)\end{array}$ \\
\hline M univ & $\begin{array}{l}0.006 \\
(0.023)\end{array}$ & $\begin{array}{l}-0.013 \\
(0.025)\end{array}$ & $\begin{array}{l}-0.040 \\
(0.024)\end{array}$ & $\begin{array}{l}0.067^{* *} \\
(0.022)\end{array}$ & $\begin{array}{l}-0.011 \\
(0.021)\end{array}$ & $\begin{array}{l}-0.025 \\
(0.021)\end{array}$ & $\begin{array}{l}-0.021 \\
(0.020)\end{array}$ & $\begin{array}{l}-0.014 \\
(0.018)\end{array}$ & $\begin{array}{l}-0.019 \\
(0.016)\end{array}$ \\
\hline M unknown & $\begin{array}{l}-0.093 \\
(0.053)\end{array}$ & $\begin{array}{l}-0.079 \\
(0.057)\end{array}$ & $\begin{array}{l}0.060 \\
(0.055)\end{array}$ & $\begin{array}{l}-0.062 \\
(0.052)\end{array}$ & $\begin{array}{l}0.031 \\
(0.049)\end{array}$ & $\begin{array}{l}-0.013 \\
(0.048)\end{array}$ & $\begin{array}{l}0.071 \\
(0.047)\end{array}$ & $\begin{array}{l}-0.067 \\
(0.039)\end{array}$ & $\begin{array}{l}-0.005 \\
(0.037)\end{array}$ \\
\hline $\mathrm{F}<$ high sch & $\begin{array}{l}0.008 \\
(0.027)\end{array}$ & $\begin{array}{l}-0.005 \\
(0.027)\end{array}$ & $\begin{array}{l}0.011 \\
(0.028)\end{array}$ & $\begin{array}{l}-0.016 \\
(0.025)\end{array}$ & $\begin{array}{l}-0.011 \\
(0.025)\end{array}$ & $\begin{array}{l}0.022 \\
(0.025)\end{array}$ & $\begin{array}{l}0.097^{\star *} \\
(0.024)\end{array}$ & $\begin{array}{l}0.010 \\
(0.021)\end{array}$ & $\begin{array}{l}0.054^{\star *} \\
(0.021)\end{array}$ \\
\hline F> high sch & $\begin{array}{l}-0.019 \\
(0.025)\end{array}$ & $\begin{array}{l}-0.025 \\
(0.026)\end{array}$ & $\begin{array}{l}0.018 \\
(0.026)\end{array}$ & $\begin{array}{l}-0.014 \\
(0.023)\end{array}$ & $\begin{array}{l}-0.041 \\
(0.023)\end{array}$ & $\begin{array}{l}-0.005 \\
(0.022)\end{array}$ & $\begin{array}{l}0.048^{*} \\
(0.020)\end{array}$ & $\begin{array}{l}-0.019 \\
(0.018)\end{array}$ & $\begin{array}{l}0.029 \\
(0.017)\end{array}$ \\
\hline F unknown & $\begin{array}{l}0.050 \\
(0.063)\end{array}$ & $\begin{array}{l}0.074 \\
(0.061)\end{array}$ & $\begin{array}{l}-0.023 \\
(0.054)\end{array}$ & $\begin{array}{l}-0.005 \\
(0.050)\end{array}$ & $\begin{array}{l}-0.050 \\
(0.049)\end{array}$ & $\begin{array}{l}-0.003 \\
(0.046)\end{array}$ & $\begin{array}{l}-0.035 \\
(0.038)\end{array}$ & $\begin{array}{l}0.007 \\
(0.039)\end{array}$ & $\begin{array}{l}-0.025 \\
(0.033)\end{array}$ \\
\hline Observations & 3253 & 3422 & 3507 & 4083 & 4404 & 4492 & 4543 & 5066 & 5243 \\
\hline
\end{tabular}

Notes: Discrete changes. Robust SE in parenthesis.* significant at $5 \%$, ** significant at $1 \%$. References are; y95, Nordic and $\mathrm{W}$ eu, social science, $\mathrm{M}$ high sch, F high sch. 
Tabel A6. Risk of leaving unemployment, across graduation years

\begin{tabular}{|c|c|c|c|c|c|c|c|}
\hline & 1991-1993 & 1992-1994 & 1993-1995 & 1994-1996 & 1995-1997 & 1996-1998 & 1997-1999 \\
\hline 3 month & $\begin{array}{l}4.386^{\star *} \\
(0.466)\end{array}$ & $\begin{array}{l}5.259^{* *} \\
(0.447)\end{array}$ & $\begin{array}{l}6.045^{\star *} \\
(0.440)\end{array}$ & $\begin{array}{l}6.403^{\star *} \\
(0.422)\end{array}$ & $\begin{array}{l}6.123^{\star *} \\
(0.419)\end{array}$ & $\begin{array}{l}5.336^{\star *} \\
(0.395)\end{array}$ & $\begin{array}{l}4.881^{\star \star} \\
(0.388)\end{array}$ \\
\hline \multirow[t]{2}{*}{6 month } & -0.577 & $-1.006^{\star *}$ & $-1.563^{\star *}$ & $-1.813^{\star *}$ & $-1.833^{\star *}$ & $-2.047^{* *}$ & $-2.116^{\star *}$ \\
\hline & $(0.337)$ & $(0.318)$ & $(0.308)$ & $(0.300)$ & $(0.303)$ & $(0.319)$ & $(0.334)$ \\
\hline \multirow[t]{2}{*}{12 month } & $0.457^{*}$ & $0.635^{\star \star}$ & $0.727^{\star *}$ & $0.712^{* *}$ & $0.581^{* *}$ & $0.510^{* *}$ & $0.601^{* *}$ \\
\hline & $(0.186)$ & $(0.174)$ & $(0.173)$ & $(0.171)$ & $(0.175)$ & (0.187) & $(0.201)$ \\
\hline \multirow[t]{2}{*}{18 month } & $1.525^{\star \star}$ & $1.374^{\star *}$ & $1.232^{* *}$ & $1.429^{\star \star}$ & $1.654^{\star *}$ & $1.870^{\star \star}$ & $1.473^{\star *}$ \\
\hline & $(0.241)$ & $(0.218)$ & $(0.219)$ & $(0.218)$ & $(0.233)$ & $(0.255)$ & $(0.290)$ \\
\hline \multirow[t]{2}{*}{24 month } & -0.473 & 0.172 & 0.557 & 0.349 & -0.414 & -0.955 & -0.653 \\
\hline & $(0.529)$ & $(0.437)$ & $(0.412)$ & $(0.430)$ & $(0.504)$ & $(0.622)$ & $(0.735)$ \\
\hline \multirow[t]{2}{*}{ Constant } & $3.601^{*}$ & $3.401^{*}$ & $5.246^{* *}$ & $4.481^{* *}$ & $9.048^{* *}$ & $9.573^{* *}$ & $7.638^{* *}$ \\
\hline & $(0.607)$ & $(0.568)$ & $(0.540)$ & $(0.506)$ & $(0.521)$ & $(0.482)$ & $(0.503)$ \\
\hline \multirow[t]{2}{*}{ Spring } & $0.741^{* *}$ & $0.814^{* *}$ & $0.829^{* *}$ & $0.863^{* *}$ & $0.869^{* *}$ & $0.879^{* *}$ & $0.898^{\star}$ \\
\hline & $(0.045)$ & $(0.042)$ & $(0.041)$ & $(0.040)$ & $(0.041)$ & $(0.043)$ & $(0.044)$ \\
\hline \multirow[t]{2}{*}{ Women } & 1.021 & 0.981 & 0.978 & 0.996 & 1.013 & 1.283 & 0.989 \\
\hline & $(0.045)$ & $(0.042)$ & $(0.041)$ & $(0.040)$ & $(0.040)$ & $(0.042)$ & $(0.045)$ \\
\hline \multirow[t]{2}{*}{ Age } & $0.914^{*}$ & $0.903^{* *}$ & $0.878^{* *}$ & $0.886^{* *}$ & $0.864^{* *}$ & $0.876^{\star *}$ & $0.898^{* *}$ \\
\hline & $(0.035)$ & $(0.033)$ & $(0.031)$ & (0.029) & $(0.030)$ & $(0.028)$ & $(0.028)$ \\
\hline \multirow[t]{2}{*}{ Age2 } & 1.001 & 1.001 & $1.001^{* *}$ & $1.001^{*}$ & $1.001^{* *}$ & $1.001^{* *}$ & $1.001^{* *}$ \\
\hline & $(0.000)$ & $(0.000)$ & $(0.000)$ & $(0.000)$ & $(0.000)$ & $(0.000)$ & $(0.000)$ \\
\hline \multirow[t]{2}{*}{ Swe } & 1.101 & $1.228^{*}$ & 1.241 & $1.261^{*}$ & 1.036 & 1.052 & 1.070 \\
\hline & $(0.095)$ & $(0.095)$ & $(0.108)$ & $(0.112)$ & $(0.103)$ & $(0.100)$ & (0.099) \\
\hline \multirow[t]{2}{*}{ Outside W eu } & 0.808 & 0.911 & 0.930 & 1.023 & 0.880 & 0.858 & 0.861 \\
\hline & $(0.138)$ & $(0.126)$ & $(0.132)$ & $(0.129)$ & $(0.123)$ & $(0.119)$ & $(0.119)$ \\
\hline \multirow[t]{2}{*}{ Child 0-3y } & 0.964 & 0.940 & 0.866 & 1.003 & 0.986 & 1.061 & 1.017 \\
\hline & $(0.089)$ & $(0.081)$ & $(0.076)$ & $(0.071)$ & $(0.075)$ & $(0.077)$ & $(0.082)$ \\
\hline \multirow[t]{2}{*}{ Child 4-6y } & 0.926 & 1.084 & $1.321^{*}$ & $1.294^{\star *}$ & 1.181 & 1.013 & 1.021 \\
\hline & $(0.123)$ & $(0.118)$ & $(0.109)$ & $(0.092)$ & (0.092) & $(0.086)$ & $(0.096)$ \\
\hline \multirow[t]{2}{*}{ Child 7-10y } & $1.400^{* *}$ & $1.326^{* *}$ & 1.091 & 1.027 & 0.981 & 1.164 & $1.215^{\star}$ \\
\hline & $(0.104)$ & $(0.089)$ & $(0.107)$ & $(0.103)$ & $(0.108)$ & $(0.096)$ & $(0.094)$ \\
\hline \multirow[t]{2}{*}{ Child 11-5y } & 0.923 & 1.086 & 1.133 & 1.188 & 1.066 & 1.193 & 1.118 \\
\hline & $(0.111)$ & $(0.101)$ & $(0.107)$ & $(0.111)$ & $(0.115)$ & $(0.110)$ & $(0.099)$ \\
\hline \multirow[t]{2}{*}{ Child 16-17y } & 1.235 & 1.041 & 1.057 & 0.967 & 1.142 & 1.051 & 1.109 \\
\hline & $(0.109)$ & $(0.133)$ & $(0.150)$ & $(0.173)$ & $(0.162)$ & $(0.153)$ & $(0.116)$ \\
\hline \multirow[t]{2}{*}{ Teacher } & $1.502^{\star *}$ & $1.674^{* *}$ & $1.579^{* *}$ & $1.381^{* *}$ & $1.192^{*}$ & $1.223^{\star *}$ & $1.273^{* *}$ \\
\hline & $(0.080)$ & $(0.076)$ & $(0.074)$ & $(0.070)$ & $(0.074)$ & $(0.074)$ & $(0.076)$ \\
\hline \multirow[t]{2}{*}{ Hum } & $1.199^{\star}$ & 1.085 & 1.023 & 0.938 & 0.920 & $0.857^{\star *}$ & 0.914 \\
\hline & $(0.083)$ & $(0.071)$ & $(0.064)$ & $(0.057)$ & $(0.057)$ & $(0.060)$ & $(0.066)$ \\
\hline Science & 1.101 & 1.084 & 1.023 & 1.036 & 1.030 & 1.019 & 0.799 \\
\hline & $(0.078)$ & $(0.069)$ & $(0.069)$ & $(0.072)$ & $(0.071)$ & (0.069) & $(0.068)$ \\
\hline Technology & 1.141 & 1.178 & $1.772^{* *}$ & $1.648^{\star *}$ & $1.708^{* *}$ & 1.265 & $1.426^{\star *}$ \\
\hline & $(0.125)$ & $(0.126)$ & $(0.148)$ & $(0.130)$ & $(0.123)$ & $(0.157)$ & $(0.131)$ \\
\hline Healthcare & $1.798^{* *}$ & $1.682^{* *}$ & $1.770^{* *}$ & $1.800^{* *}$ & $1.946^{\star *}$ & $1.758^{\star \star}$ & $1.773^{\star *}$ \\
\hline & $(0.088)$ & $(0.084)$ & $(0.080)$ & $(0.076)$ & $(0.080)$ & $(0.077)$ & $(0.074)$ \\
\hline Service & 0.905 & 0.911 & 0.609 & 0.832 & 0.831 & 0.808 & 0.966 \\
\hline & $(0.653)$ & $(0.604)$ & $(0.415)$ & $(0.261)$ & $(0.021)$ & $(0.178)$ & $(0.212)$ \\
\hline Educ $<3 y$ & $0.808^{*}$ & 0.947 & 0.871 & 0.814 & 0.811 & 0.980 & $1.381^{*}$ \\
\hline & $(0.103)$ & $(0.108)$ & $(0.122)$ & $(0.125)$ & $(0.128)$ & $(0.138)$ & $(0.132)$ \\
\hline Educ $>3 y$ & $1.195^{\star *}$ & $1.191^{* *}$ & $1.151^{* *}$ & $1.135^{\star *}$ & $1.104^{*}$ & $1.115^{\star}$ & 1.050 \\
\hline & $(0.049)$ & $(0.044)$ & $(0.042)$ & $(0.041)$ & $(0.041)$ & $(0.043)$ & $(0.046)$ \\
\hline$M<$ high sch & 0.950 & 0.994 & 1.028 & 1.161 & 1.008 & 0.976 & 0.969 \\
\hline & $(0.064)$ & $(0.062)$ & $(0.061)$ & $(0.060)$ & $(0.063)$ & $(0.065)$ & $(0.066)$ \\
\hline M univ & 1.066 & 1.052 & 1.021 & 1.009 & 0.977 & 0.957 & 1.007 \\
\hline & $(0.059)$ & $(0.055)$ & $(0.053)$ & $(0.052)$ & $(0.052)$ & $(0.055)$ & $(0.056)$ \\
\hline M unknown & 0.931 & 0.910 & 1.074 & 1.007 & 1.088 & 0.956 & 0.841 \\
\hline
\end{tabular}




$\begin{array}{llllllll} & (0.139) & (0.119) & (0.108) & (0.109) & (0.101) & (0.109) & (0.130) \\ \text { F < high sch } & 0.971 & 0.980 & 1.035 & 1.041 & 0.977 & 0.901 & 0.940 \\ & (0.066) & (0.062) & (0.060) & (0.061) & (0.062) & (0.066) & (0.069) \\ \text { F> high sch } & 0.987 & 0.991 & 1.035 & 1.062 & 1.029 & 0.967 & 1.003 \\ & (0.063) & (0.057) & (0.054) & (0.053) & (0.054) & (0.057) & (0.061) \\ \text { F unknown } & 1.039 & 1.004 & 0.934 & 0.936 & 0.973 & 0.950 & 0.972 \\ & (0.121) & (0.113) & (0.117) & (0.109) & (0.116) & (0.120) & (0.135) \\ \text { Obs } & 2224 & 2592 & 2706 & 2815 & 2693 & 2461 & 2246\end{array}$

Notes: Exp (coeff) are presented..Robust SE in parenthesis.* significant at 5\%, ** significant at $1 \%$. References are; y95, Nordic and W eu, social science, M high sch, F high sch.

Tabel A7. Models; (i) The hazard model including unobserved heterogeneity (ii) The probit and Hazard model estimated simultaneously and (iii) The probit model, estimated using the simultaneous sample.

\begin{tabular}{|c|c|c|c|c|}
\hline & (i) & & (ii) & (iii) \\
\hline & $\begin{array}{l}\text { Hazard } \\
\text { (including unobserved } \\
\text { heterogeneity) }\end{array}$ & Hazard & Probit & $\begin{array}{l}\text { Probit } \\
\text { (estimated using } \\
\text { the simultaneous } \\
\text { sample) } \\
\end{array}$ \\
\hline Spring & $\begin{array}{l}0.792^{* *} \\
(0.034)\end{array}$ & $\begin{array}{l}0.792^{* *} \\
(0.034)\end{array}$ & $\begin{array}{l}-0.429^{* \star} \\
(0.034)\end{array}$ & $\begin{array}{l}-0.220^{\star *} \\
(0.017)\end{array}$ \\
\hline Women & $\begin{array}{l}1.005 \\
(0.034)\end{array}$ & $\begin{array}{l}1.004 \\
(0.034)\end{array}$ & $\begin{array}{l}0.065 \\
(0.034)\end{array}$ & $\begin{array}{l}0.032 \\
(0.017)\end{array}$ \\
\hline Age & $\begin{array}{l}0.872^{* *} \\
(0.026)\end{array}$ & $\begin{array}{l}0.872^{* *} \\
(0.026)\end{array}$ & $\begin{array}{l}0.144^{* *} \\
(0.025)\end{array}$ & $\begin{array}{l}0.072^{* *} \\
(0.011)\end{array}$ \\
\hline Age2 & $\begin{array}{l}1.001^{* *} \\
(0.000)\end{array}$ & $\begin{array}{l}1.001^{* *} \\
(0.004)\end{array}$ & $\begin{array}{l}-0.002^{* *} \\
(0.000)\end{array}$ & $\begin{array}{l}-0.001^{* *} \\
(0.000)\end{array}$ \\
\hline Swe & $\begin{array}{l}1.206^{*} \\
(0.083)\end{array}$ & $\begin{array}{l}1.207^{*} \\
(0.083)\end{array}$ & $\begin{array}{l}-0.454^{* *} \\
(0.096)\end{array}$ & $\begin{array}{l}-0.224^{* *} \\
(0.044)\end{array}$ \\
\hline Outside W eu & $\begin{array}{l}0.835 \\
(0.103)\end{array}$ & $\begin{array}{l}0.834 \\
(0.104)\end{array}$ & $\begin{array}{l}0.331^{*} \\
(0.131)\end{array}$ & $\begin{array}{l}0.125^{\star} \\
(0.055)\end{array}$ \\
\hline Child 0-3y & $\begin{array}{l}1.009 \\
(0.064)\end{array}$ & $\begin{array}{l}1.010 \\
(0.064)\end{array}$ & $\begin{array}{l}-0.195^{\star *} \\
(0.059)\end{array}$ & $\begin{array}{l}-0.100^{* *} \\
(0.031)\end{array}$ \\
\hline Child 4-6y & $\begin{array}{l}1.119 \\
(0.081)\end{array}$ & $\begin{array}{l}1.120 \\
(0.081)\end{array}$ & $\begin{array}{l}0.090 \\
(0.073)\end{array}$ & $\begin{array}{l}0.053 \\
(0.039)\end{array}$ \\
\hline Child 7-10y & $\begin{array}{l}1.260^{* *} \\
(0.083)\end{array}$ & $\begin{array}{l}1.260^{* *} \\
(0.084)\end{array}$ & $\begin{array}{l}-0.021 \\
(0.073)\end{array}$ & $\begin{array}{l}-0.012 \\
(0.039)\end{array}$ \\
\hline Child 11-5y & $\begin{array}{l}1.140 \\
(0.092)\end{array}$ & $\begin{array}{l}1.142 \\
(0.093)\end{array}$ & $\begin{array}{l}-0.293^{* *} \\
(0.073)\end{array}$ & $\begin{array}{l}-0.156^{\star *} \\
(0.039)\end{array}$ \\
\hline Child 16-17y & $\begin{array}{l}1.084 \\
(0.109)\end{array}$ & $\begin{array}{l}1.084 \\
(0.110)\end{array}$ & $\begin{array}{l}0.002 \\
(0.094)\end{array}$ & $\begin{array}{l}0.001 \\
(0.049)\end{array}$ \\
\hline Teacher & $\begin{array}{l}1.593^{* *} \\
(0.644)\end{array}$ & $\begin{array}{l}1.594^{* *} \\
(0.064)\end{array}$ & $\begin{array}{l}0.062 \\
(0.053)\end{array}$ & $\begin{array}{l}0.044 \\
(0.029)\end{array}$ \\
\hline Hum & $\begin{array}{l}0.811 \\
(0.055)\end{array}$ & $\begin{array}{l}0.979 \\
(0.055)\end{array}$ & $\begin{array}{l}0.238^{* *} \\
(0.056)\end{array}$ & $\begin{array}{l}0.104^{* *} \\
(0.026)\end{array}$ \\
\hline Science & $\begin{array}{l}1.057 \\
(0.058)\end{array}$ & $\begin{array}{l}1.059 \\
(0.058)\end{array}$ & $\begin{array}{l}-0.678^{* *} \\
(0.050)\end{array}$ & $\begin{array}{l}-0.365^{\star *} \\
(0.027)\end{array}$ \\
\hline Technology & $\begin{array}{l}1.545^{\star *} \\
(0.102)\end{array}$ & $\begin{array}{l}1.548^{\star *} \\
(0.102)\end{array}$ & $\begin{array}{l}-0.691^{* *} \\
(0.082)\end{array}$ & $\begin{array}{l}0.375^{\star \star} \\
(0.045)\end{array}$ \\
\hline Healthcare & $\begin{array}{l}2.245^{\star *} \\
(0.777)\end{array}$ & $\begin{array}{l}2.249^{* *} \\
(0.078)\end{array}$ & $\begin{array}{l}-0.551^{* *} \\
(0.052)\end{array}$ & $\begin{array}{l}-0.310^{\star *} \\
(0.028)\end{array}$ \\
\hline Service & $\begin{array}{l}0.965 \\
(0.233)\end{array}$ & $\begin{array}{l}0.963 \\
(0.234)\end{array}$ & $\begin{array}{l}0.923 \\
(0.315)\end{array}$ & $\begin{array}{l}0.379^{\star *} \\
(0.114)\end{array}$ \\
\hline Educ $<3 y$ & $\begin{array}{l}0.921 \\
(0.097)\end{array}$ & $\begin{array}{l}0.922 \\
(0.097)\end{array}$ & $\begin{array}{l}0.184^{\star *} \\
(0.034)\end{array}$ & $\begin{array}{l}0.100^{\star *} \\
(0.017)\end{array}$ \\
\hline Educ $>3 y$ & $\begin{array}{l}1.132^{\star *} \\
(0.035)\end{array}$ & $\begin{array}{l}1.132^{\star *} \\
(0.035)\end{array}$ & $\begin{array}{l}-0.269^{\star *} \\
(0.069)\end{array}$ & $\begin{array}{l}-0.164^{\star *} \\
(0.038)\end{array}$ \\
\hline
\end{tabular}




\begin{tabular}{|c|c|c|c|c|}
\hline$M<$ high sch & $\begin{array}{l}0.991 \\
(0.052)\end{array}$ & $\begin{array}{l}0.991 \\
(0.052)\end{array}$ & $\begin{array}{l}-0.026 \\
(0.047)\end{array}$ & $\begin{array}{l}-0.013 \\
(0.025)\end{array}$ \\
\hline M univ & $\begin{array}{l}1.050 \\
(0.043)\end{array}$ & $\begin{array}{l}1.050 \\
(0.043)\end{array}$ & $\begin{array}{l}-0.014 \\
(0.042)\end{array}$ & $\begin{array}{l}-0.004 \\
(0.022)\end{array}$ \\
\hline M unknown & $\begin{array}{l}0.911 \\
(0.097)\end{array}$ & $\begin{array}{l}0.911 \\
(0.097)\end{array}$ & $\begin{array}{l}0.017 \\
(0.099)\end{array}$ & $\begin{array}{l}0.007 \\
(0.052)\end{array}$ \\
\hline $\mathrm{F}<$ high sch & $\begin{array}{l}0.971 \\
(0.052)\end{array}$ & $\begin{array}{l}0.971 \\
(0.052)\end{array}$ & $\begin{array}{l}0.074 \\
(0.048)\end{array}$ & $\begin{array}{l}0.029 \\
(0.026)\end{array}$ \\
\hline F> high sch & $\begin{array}{l}1.031 \\
(0.045)\end{array}$ & $\begin{array}{l}1.032 \\
(0.046)\end{array}$ & $\begin{array}{l}-0.018 \\
(0.043)\end{array}$ & $\begin{array}{l}-0.014 \\
(0.023)\end{array}$ \\
\hline F unknown & $\begin{array}{l}0.926 \\
(0.096)\end{array}$ & $\begin{array}{l}0.926 \\
(0.096)\end{array}$ & $\begin{array}{l}-0.064 \\
(0.092)\end{array}$ & $\begin{array}{l}-0.034 \\
(0.049)\end{array}$ \\
\hline y91 & $\begin{array}{l}1.176^{\star} \\
(0.076)\end{array}$ & $\begin{array}{l}1.176^{*} \\
(0.076)\end{array}$ & - & - \\
\hline y92 & $\begin{array}{l}0.893 \\
(0.064)\end{array}$ & $\begin{array}{l}0.893 \\
(0.065)\end{array}$ & - & - \\
\hline y93 & $\begin{array}{l}0.831^{* *} \\
(0.067)\end{array}$ & $\begin{array}{l}0.831^{* *} \\
(0.067)\end{array}$ & - & - \\
\hline y94 & $\begin{array}{l}0.968 \\
(0.063)\end{array}$ & $\begin{array}{l}0.968 \\
(0.063)\end{array}$ & - & - \\
\hline y96 & $\begin{array}{l}1.118 \\
(0.065)\end{array}$ & $\begin{array}{l}1.118 \\
(0.065)\end{array}$ & - & - \\
\hline y97 & $\begin{array}{l}1.304^{\star *} \\
(0.067)\end{array}$ & $\begin{array}{l}1.306^{\star *} \\
(0.067)\end{array}$ & - & - \\
\hline y98 & $\begin{array}{l}1.698^{\star \star} \\
(0.072)\end{array}$ & $\begin{array}{l}1.701^{\star *} \\
(0.072)\end{array}$ & - & - \\
\hline y99 & $\begin{array}{l}1.805^{\star *} \\
(0.075)\end{array}$ & $\begin{array}{l}1.809^{* *} \\
(0.075)\end{array}$ & - & - \\
\hline 1991-1993 & - & - & $\begin{array}{l}0.005 \\
(0.040)\end{array}$ & $\begin{array}{l}-0.007 \\
(0.020)\end{array}$ \\
\hline 1997-1999 & - & - & $\begin{array}{l}-0.621^{* *} \\
(0.037)\end{array}$ & $\begin{array}{l}-0.334^{* *} \\
(0.019)\end{array}$ \\
\hline 3 month & $\begin{array}{l}6.613^{\star *} \\
(0.378)\end{array}$ & $\begin{array}{l}6.621^{* *} \\
(0.377)\end{array}$ & - & - \\
\hline 6 month & $\begin{array}{l}-0.447 \\
(0.254)\end{array}$ & $\begin{array}{l}-0.440 \\
(0.254)\end{array}$ & - & - \\
\hline 12 month & $\begin{array}{l}1.309^{\star *} \\
(0.153)\end{array}$ & $\begin{array}{l}1.312^{\star *} \\
(0.152)\end{array}$ & - & - \\
\hline 18 month & $\begin{array}{l}2.264^{* *} \\
(0.181)\end{array}$ & $\begin{array}{l}2.267^{* *} \\
(0.181)\end{array}$ & - & - \\
\hline 24 month & $\begin{array}{l}0.739^{\star} \\
(0.365)\end{array}$ & $\begin{array}{l}0.749^{*} \\
(0.366)\end{array}$ & - & - \\
\hline Constant & $\begin{array}{l}5.267^{* *} \\
(0.446)\end{array}$ & $\begin{array}{l}5.291^{* *} \\
(0.448)\end{array}$ & $\begin{array}{l}-3.319^{* *} \\
(0.505)\end{array}$ & $\begin{array}{l}-1.203^{\star *} \\
(0.196)\end{array}$ \\
\hline Sigma 1 & $\begin{array}{l}2.202 \\
(0.078)\end{array}$ & - & - & - \\
\hline Sigma 2 & - & - & - & - \\
\hline Roh & - & - & - & - \\
\hline Obs & 7285 & 7285 & 7285 & 7285 \\
\hline
\end{tabular}

Notes: Exp (coeff) are presented. Robust SE in parenthesis.* significant at $5 \%, * *$ significant at $1 \%$. References are; y95, Nordic and W eu, social science, M high sch, F high sch. 